IOS Press

\title{
Review
}

\section{Combining Stem Cells and Biomaterial Scaffolds for Constructing Tissues and Cell Delivery}

\author{
Stephanie M. Willerth ${ }^{\mathrm{a}, \mathrm{b}, \mathrm{c}}$ and Shelly E. Sakiyama-Elbert ${ }^{\mathrm{d}, *}$ \\ ${ }^{a}$ Department of Mechanical Engineering, University of Victoria, VIC, Canada \\ ${ }^{\mathrm{b}}$ Division of Medical Sciences, University of Victoria, VIC, Canada \\ ${ }^{\mathrm{c}}$ International Collaboration on Repair Discoveries, University of British Columbia, Vancouver, Canada \\ ${ }^{\mathrm{d}}$ Department of Biomedical Engineering, University of Texas-Austin, Austin, TX, USA
}

Accepted: 11 December 2018

\begin{abstract}
Combining stem cells with biomaterial scaffolds serves as a promising strategy for engineering tissues for both in vitro and in vivo applications. This updated review details commonly used biomaterial scaffolds for engineering tissues from stem cells. We first define the different types of stem cells and their relevant properties and commonly used scaffold formulations. Next, we discuss natural and synthetic scaffold materials typically used when engineering tissues, along with their associated advantages and drawbacks and gives examples of target applications. New approaches to engineering tissues, such as $3 \mathrm{D}$ bioprinting, are described as they provide exciting opportunities for future work along with current challenges that must be addressed. Thus, this review provides an overview of the available biomaterials for directing stem cell differentiation as a means of producing replacements for diseased or damaged tissues.
\end{abstract}

Keywords: Tissue engineering, pluripotent stem cells, adult stem cells, bioprinting

\section{INTRODUCTION}

Since the initial publication of our STEMBOOK chapter in 2008 [1], the field of stem biology has advanced rapidly as such regenerative medicine strategies move into clinical trials for a variety of health disorders [2]. Stem cells possess two novel properties - the ability to produce additional stem cells and the capacity to become multiple cell types [3]. Table 1 lists the major types of stem cells and their associated properties. These types include adult, embryonic, fetal, induced pluripotent, and

\footnotetext{
${ }^{*}$ Correspondence to: Dr. Shelly Sakiyama-Elbert, Department of Biomedical Engineering, University of Texas-Austin, 107 West Dean Keeton St., Austin, TX 78712, USA. Tel.: +1 512471 3604; E-mail: sakiyama@utexas.edu.
}

mesenchymal stem cells. In particular, the discovery of induced pluripotent stem cells (iPSCs) in 2006 catalyzed the fields of tissue engineering and regenerative medicine as they represented a major advance in stem cell technology [4]. These iPSC lines can be generated from patient-derived cells, making it possible to obtain personalized stem cell lines.

Tissue engineering combines biomaterial scaffolds with these different types of cells to replace damaged organs. The differentiation potential of stem cells makes them a valuable tool for such applications. In 1987, a group of experts defined the word biomaterial as "a non-viable material used in a medical device, intended to interact with biological systems" [5]. This definition reflected the state of the field at the time, which focused on the development of 
Table 1

Different types of stem cells and their associated properties

\begin{tabular}{|c|c|c|}
\hline Type of Stem Cells & Source & Differentiation potential \\
\hline Adult stem cells & $\begin{array}{l}\text { Tissues including nerve, skin, } \\
\text { cardiac, bone, blood, gut, } \\
\text { liver, and teeth }\end{array}$ & $\begin{array}{l}\text { Limited to the tissue from } \\
\text { which they were derived }\end{array}$ \\
\hline Embryonic stem cells & $\begin{array}{l}\text { Derived from the inner cell } \\
\text { mass of a blastocyst }\end{array}$ & $\begin{array}{l}\text { Can become any cell type } \\
\text { from the organism from } \\
\text { which they were derived }\end{array}$ \\
\hline Fetal stem cells & $\begin{array}{l}\text { Derived from the tissues of } \\
\text { fetuses }\end{array}$ & $\begin{array}{l}\text { Limited to the tissue from } \\
\text { which they were derived }\end{array}$ \\
\hline $\begin{array}{l}\text { Induced pluripotent stem } \\
\text { cells }\end{array}$ & $\begin{array}{l}\text { Adult cells reprogrammed } \\
\text { back into a pluripotent state }\end{array}$ & $\begin{array}{l}\text { Can become any cell type } \\
\text { from the organism from } \\
\text { which they were derived }\end{array}$ \\
\hline Mesenchymal stem cells & $\begin{array}{l}\text { A variety of sources } \\
\text { including bone marrow, fat, } \\
\text { and peripheral blood }\end{array}$ & $\begin{array}{l}\text { Can differentiate into bone, } \\
\text { cartilage, and adipose } \\
\text { tissue }\end{array}$ \\
\hline
\end{tabular}

materials and coatings to prevent the rejection of implantable medical devices. Since 1987, this field of study has expanded to include the design and development of implantable scaffolds with defined properties produced from a wide variety of biomaterials. Such biomaterial scaffolds promote the viability and differentiation of stem cells seeded inside depending on the intrinsic properties of the material as well as the incorporation of specific chemical and physical cues into the material. A wide range of natural and synthetic biomaterials have been evaluated as substrates for controlling stem cell behavior. First, the different types of scaffold formulations are defined and critically analyzed. Next, specific examples will be discussed for the three major categories of biomaterials: natural, synthetic, and ceramic-based. The advantages and drawbacks of each material type will be detailed along with relevant examples of how such scaffolds can influence stem cell behavior. This review focuses on three-dimensional (3D) scaffolds as they mimic the environment found in the human body, making them highly relevant when engineering tissues, including the use of 3D printing tissues using biomaterial-based inks. This review summarizes the current knowledge of using biomaterials in combination with stem cells for tissue engineering applications, including cell delivery to repair damaged regions of the body.

\section{TYPES OF SCAFFOLD FORMULATIONS}

Both natural and synthetic biomaterials can serve as the starting point for generating bioactive scaffolds for controlling stem cell differentiation into the desired tissue type. These scaffolds can take several different forms, which in turn have unique features.
This section will detail the properties of the following types of scaffolds: hydrogels, micro and nanofibers, and micro and nanospheres (Fig. 1). Each type of scaffold formulation possesses certain advantages and disadvantages, which will be discussed. These scaffolds can also be combined to yield novel hybrid materials as often certain formulations enable better cell survival with others providing a more desirable time course for drug delivery.

\section{Hydrogels}

Hydrogels consist of cross-linked hydrophilic polymer networks that swell upon exposure to water - hence the name [6]. The extracellular matrix (ECM) serves as a complex naturally occurring hydrogel that provides the microenvironment that supports the stem cells found resident in tissues, making this scaffold formulation highly desirable for tissue engineering applications using stem cells. Many different factors play roles in determining the properties of these hydrogels, including the properties of the polymer, degree of cross-linking, chemical functionalization, and other parameters. Hydrogels are often modified to incorporate drug delivery systems, which can enhance the survival and differentiation of the stem cells seeded inside [7-9]. They also have been used successfully to deliver stem cells in vivo and they can often be formulated to be injectable, which is highly desirable for clinical applications [10]. Recent reviews have summarized the wide body of work detailing how hydrogels have been used to successfully deliver stem cells in vivo for a variety of applications, including vascularization, tendon repair, healing kidney damage, and for neural regeneration [11-14] Ensuring long-term stability can be 


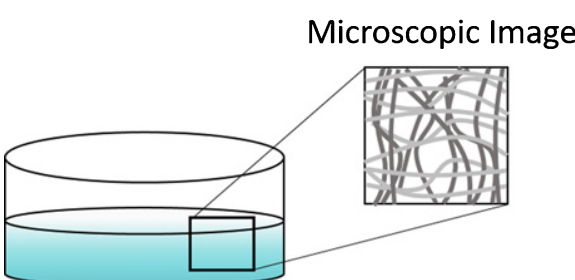

Hydrogel

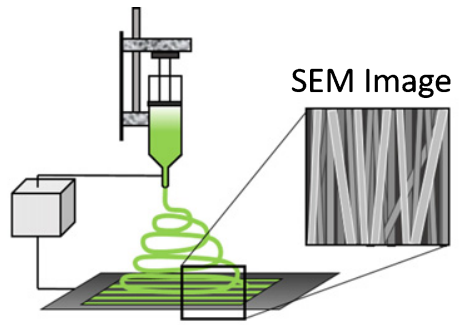

Electospun Nanofibres

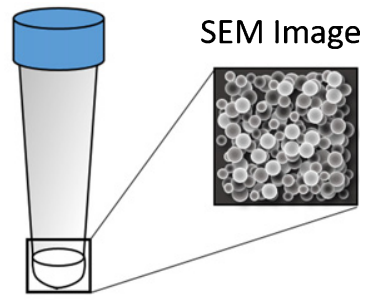

Microspheres

Fig. 1. Commonly used scaffold formulations for engineering tissues from stem cells include hydrogels, electrospun scaffolds, and nano/microspheres.

challenging as well as matching the desired release rate for molecules embedded in the hydrogel matches the desired degradation rate. However, both natural and synthetic hydrogels remain popular tools for engineering tissues from stem cells.

\section{Electrospun scaffolds}

Electrospun scaffolds serve as another popular option as scaffolds for promoting the culture and differentiation of stem cells into tissues as detailed in a recent book [15]. The process of electrospinning requires the application of a high voltage field to a polymer solution, which draws out thin fibers that are collected in a specialized fashion. Electrospinning set-ups are often inexpensive to implement and thus it has become an increasingly popular scaffold fabrication technique. Different parameters including the polymer solution being spun, the collection distance and method, the applied voltage field, and the ambient conditions all influence the size, topography, and consistency of the fibrous scaffolds produced when electrospinning [16]. The properties of these fibrous scaffolds can influence how stem cells behave, including their topography and their ability to generate controlled release of biomolecules [17]. Electrospinning can generate fibrous scaffolds ranging in size from nanometers to micrometers and the size and orientation of these fibers play an important role in controlling the behavior of the cells seeded upon such scaffolds [18]. Such topography can direct stem cells to form functional tissues, including cardiac, bone, and nerve [19-21]. Bioactive factors, such as small molecules, polysaccharides, and growth factors, can be added to the solution being spun to generate controlled release for directing stem cell behavior [22, 23]. Topography, fiber size, and fabrication parameters can all affect the release rate of such molecules and these factors can be tuned accordingly to generate a desirable release course necessary for achieving the desired effect on stem cell behavior. Some limitations of electrospinning include the reproducibility of these scaffolds as fiber size can vary significantly even within a scaffold and scale-up [20]. In conclusion, electrospun scaffolds can serve as multifunctional scaffolds for generating tissues from a variety of stem cells.

\section{Nano and microparticles}

Particles ranging in size from the nanoscale to microscale can serve as effective tools for drug delivery for a number of reasons [24, 25]. The use of such particle-based drug delivery system has several advantages. The ability to tune the encapsulation efficiency of the drug contained in the particles and the number of particles used for a particular application enables a high degree of control over the concentration and time course of the target molecule being delivered. Their size also means they can be delivered in vivo through injections and certain formulations of nanoparticles can even cross the blood-brain barrier to provide controlled drug release [26]. Such particles are often combined with hydrogels [27] and electrospun scaffolds [28] to provide additional bioactivity and deliver additional factors when engineering complex tissues. Accordingly, drug-releasing particles on both the nano and micro scale can be used to control stem cell differentiation - both alone and in combination with other scaffold formulations [29]. Different combinations of drug-releasing particles can be incorporated into such systems to yield a multifunctional construct for promoting stem cell differentiation into specific types of tissues. Such particles can also be directly incorporated into stem cell aggregates to ensure more homogenous 
differentiation as well [30]. While these applications highlight the desirable properties of drug-releasing particles, they also have certain issues associated with their use. These issues include determining proper dosage to ensure the desired effect on stem cell behavior. Also, controlling the size distribution and morphology of the particles produced depends on the method of fabrication and large variations can be observed, which is similar to limitations associated with electrospun scaffolds. However, such particle distributions can be adjusted using sieving.

\section{NATURAL BIOMATERIALS}

The proteins and polysaccharides found in the ECM provide an obvious starting point when developing scaffolds derived from natural biomaterials. These bioactive molecules perform many roles in vivo, and often contain sites for cellular adhesion while displaying inherent biocompatibility. These materials can exhibit variability depending on their source and may induce an immune response if not properly purified. These scaffolds often exhibit a limited range of mechanical properties and often their scaffold formulations need to be optimized for stem cell culture. The following sections will first focus specifically on scaffolds made from purified proteins or polysaccharides and then highlight the emerging area of using decellularized ECM for directing the differentiation of stem cells.

\section{Protein-based biomaterials}

Proteins play an important role in providing structure to tissues, making them a logical choice for tissue engineering applications requiring stem cell differentiation and transplantation. This section highlights some of the most commonly used protein-based biomaterials, including collagen, fibrin, silk, fibronectin, and vitronectin, and their application to engineering tissues from stem cells. Proteins can be isolated from human or animal sources and care must be taken to ensure that animal-derived proteins do not trigger an immune response if clinical translation remains the end goal. For example, collagen, a commonly used biomaterial, can be isolated from a variety of tissues, including skin, tendon, or bone. It can also be processed into other forms, including gelatin and gelatin methacrylate. The protein fibrin plays an essential role in the blood clotting process. It can be isolated from blood, and it is commonly used as a surgical sealant in clinical studies and as a biomaterial scaffold. Insects and worms secrete silk, which is another protein commonly used for generating tissueengineered scaffolds. Scaffolds made of silk or silk fibroin have slow degradation rates and desirable mechanical properties, providing an alternative to collagen and fibrin. Scaffolds made from silk fibers can be fabricated into a variety of structures, such as mats, sponges, meshes and membranes, expanding the possible applications. We will also discuss the use of other proteins found in the ECM as scaffolds materials for directing stem cell differentiation, including fibronectin, vitronectin, and laminin. The following sections will highlight specific examples of these scaffolds being used in combination with stem cells for a range of different tissue engineering applications.

\section{Collagen}

Collagen comprises $25 \%$ of the total protein found in the human body, making it a logical choice for tissue engineering applications [31]. Collagen contains sites for cell adhesion and its natural materials properties are similar to that of soft tissue [32]. It comes in several types with Type 1 being the most commonly used to form hydrogels as it is the most abundant in tissues. Hydrogels made from collagen can be modified to enhance their chemical and mechanical properties, which can be tailored to the desired tissue to be engineered [33]. 3D collagen hydrogels can culture a wide variety of stem cells for different tissue engineering applications, including neural tissues, blood vessels, cardiac tissue, liver and cartilage [34-44]. Collagen can also be denatured to produce gelatin, which can be modified to produce gelatin methacryloyl (GelMa) [45]. GelMA hydrogels can be produced by photo-crosslinking and its mechanical and chemical properties are easily tunable depending on the application. GelMa also exhibits decreased antigenicity as it is denatured, enhancing its relevance for clinical applications [46]. Engineering tissues by combining stem cells with GelMa hydrogels has been gaining in popularity recently, especially with $3 \mathrm{D}$ bioprinting approaches using GelMa as a novel bioink [47-49]. An interesting paper from the Khademhosseini lab showed how 3D printing different types of GelMa-derived bioinks can serve as a valuable tool for determining an optimal formulation for directing human mesenchymal stem cells (MSCs) to form bone tissue [50]. The printing set-up and experimental design can be seen in Fig. 2.

The properties of collagen can be further manipulated on the micro and nanoscale using techniques 
(A)

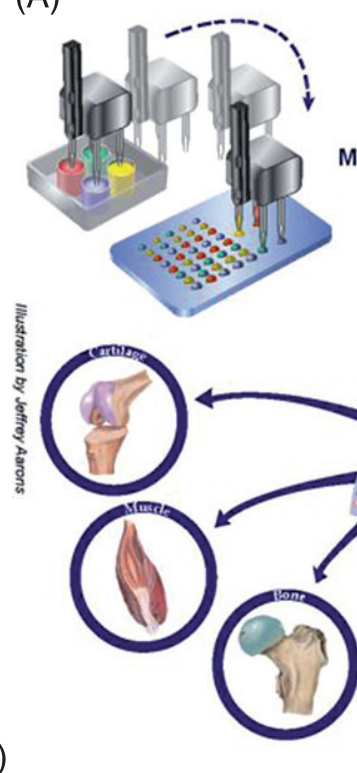

Protein encapsulation

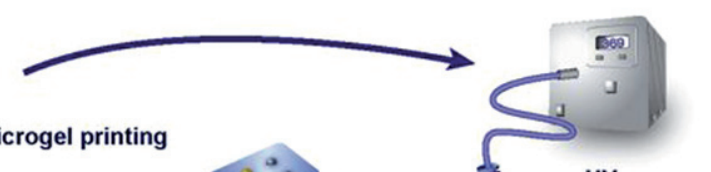

UVcrosslinking

(B) Microarray design

Protein combination = 12
1. Gelatin (GE)
2. GE-Fibronectin $(F N)$
3. GE-Laminin $(\mathrm{LN})$
4. GE-Osteocakin $20(O C N(20))$
5. GE-OCN(40)
6. GE-LN-FN
7. GE-LN-OCN(20)
8. GE-LN-OCN(40)
9. GE-FN-OCN(20)
10. GE-FN-OCN(40)
11. GE-LN-FN-OCN $(20)$
12. GE-LN-FN-OCN(40)
Media COnditions $=8$
1. Normal media (NM)
2. NM + BMP5
3. NM + BMP2
4. NM + BMP(5+2)
5. Inducing media (IM)
6. IM + BMP5
7. IM + BMP2
8. IM + BMP( $5+2)$
Total combination $=96$

Tissue engineering applications

(D)

hMSCs viability within microfabricated hydrogels
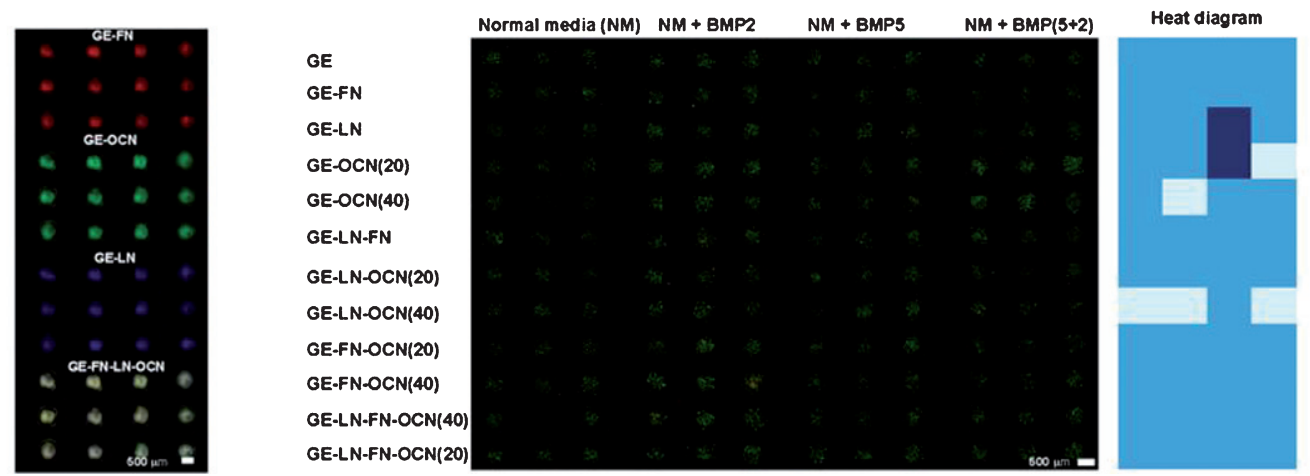

Vlability $(\%)$

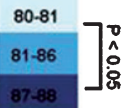

Fig. 2. A) A robotic microarray spotter was used to rapidly print droplets consisting of hMSCs, gelatin methacrylate (GE)-based prepolymer solution and various ECM proteins on TMSPMA functionalized glass slide. The printing step was followed by a 15|sec UV light exposure to form the miniaturized cell-laden constructs. Following printing, cell-laden gel microarrays were placed inside sealed chambers (Illustration made by Jeffrey Aarons). B) Various combinations of ECM proteins and media formulations were used to conduct the microarrays experiments. The concentration of $\mathrm{LN}$ and FN was selected to be $40 \mid \mu \mathrm{g} / \mathrm{ml}$ while OCN was printed at two concentrations of $20 \mid \mu \mathrm{g} / \mathrm{ml}$ and $40 \mid \mu \mathrm{g} / \mathrm{ml}$. C) Fluorescence images of the encapsulated proteins within the hydrogel constructs after 24 hours in solution. D) hMSCs viability within 48 combinatorial 3D microenvironments in normal (control) media after 7 days of culture along with color-diagram displaying the quantified cell viability $(n=3-9)$. This figure was reproduced under a Creative Commons Attribution-NonCommercial-NoDerivs 3.0 Unported License. Taken from [50].

such as electrospinning and fabrication of microspheres [51]. Electrospinning poses challenges in terms of maintaining the bioactivity of the protein, but it can be achieved under appropriate conditions $[52,53]$. Collagen is often added to synthetic polymer scaffolds to enhance their bioactivity and enable stem cells to bind to these scaffolds [54, 55]. Both collagen and gelatin microspheres can be seeded with stem cells as a novel approach to tissue engineering.
Collagen microspheres are commonly used to deliver a variety of stem cells ranging from mesenchymal stem cells to oligodendrocyte progenitors [56-58]. A recent study also highlighted how GelMa microspheres containing bone marrow-derived stem cells could be injected in vivo for bone tissue engineering application [59]. Thus, collagen and the related polymer-GelMa-serve as powerful tools for engineering tissues from stem cells. 

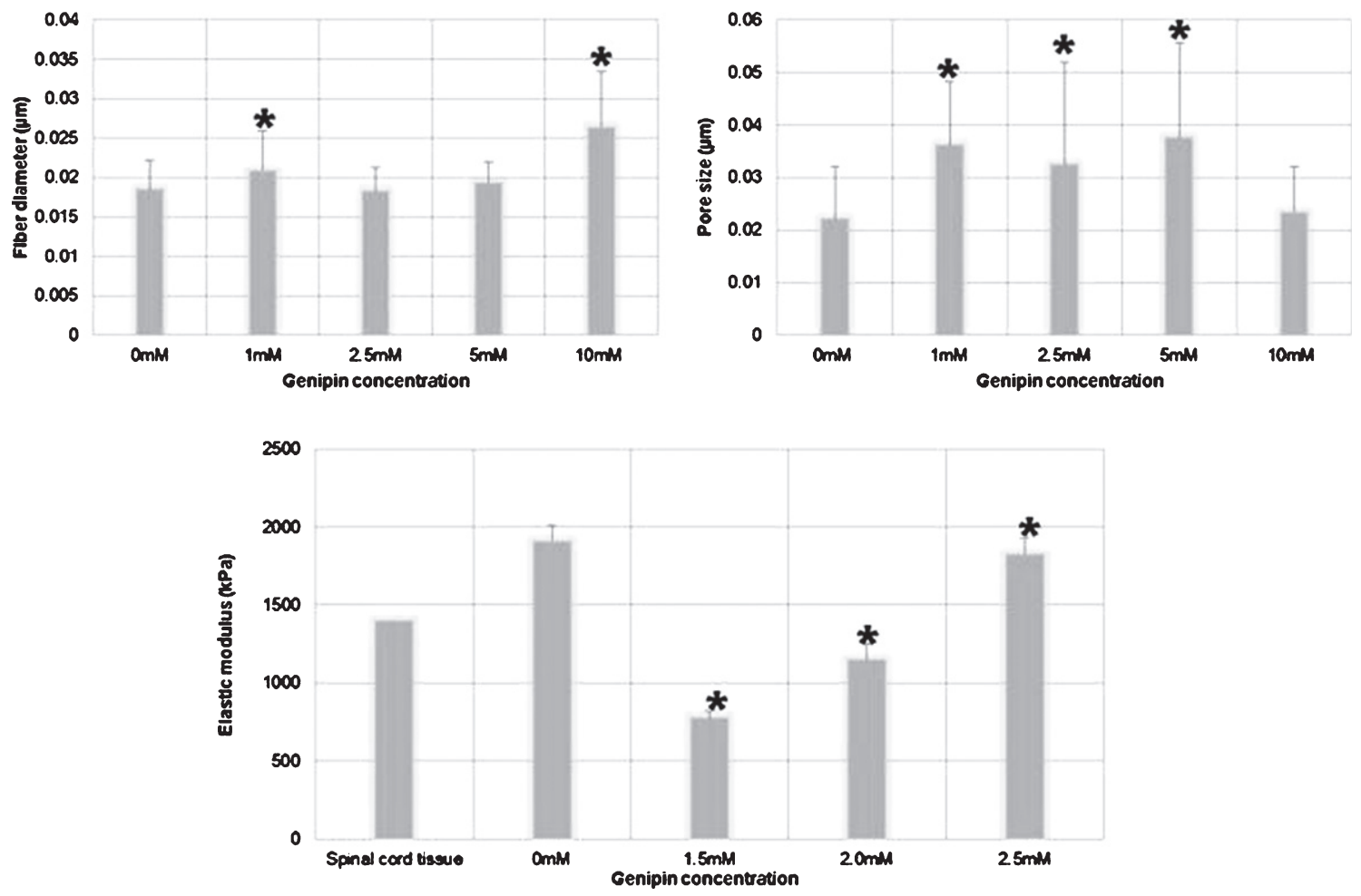

Fig. 3. Genipin crosslinking influences the morphological and mechanical properties of fibrin scaffolds. The effect of genipin concentration on fiber diameter (biological $n=3$, technical $n=10$, shown on the top left). The effect of genipin concentration on pore size of fibrin scaffolds (biological $n=3$, technical $n=30$, shown on the top right). The effect of genipin on elastic modulus (shown on the bottom). The elastic modulus for spinal cord tissue is taken from 37. Each group is represented by its mean average with error bars indicating the S.E.M. *Indicates $p<0.05$ compared to control $(0 \mathrm{mM})$. This figure was reproduced under a Creative Commons Attribution-NonCommercial-NoDerivs 3.0 Unported License. Taken from [61].

\section{Fibrin}

Similar to collagen, fibrin exhibits natural biocompatibility and contains sites for cell adhesion [60]. Accordingly, significant work has been performed evaluating fibrin scaffolds for directing the differentiation of different types of stem cells. As mentioned earlier, fibrinogen circulates in the bloodstream and becomes polymerized into fibrin clots during the wound healing process [61]. Surgeons use fibrin as surgical glue, making it a desirable material for clinical translation [62]. It can be used to generate hydrogels, electrospun scaffolds, and microspheres that serve as cell carriers for a wide variety of tissue engineering applications [63-65]. Additionally, its mechanical properties can be manipulated to ensure a proper environment for stem cell differentiation as seen in Fig. 3 [66]. Many groups have investigated a variety of fibrin hydrogel formulations for engineering neural tissue from stem cells, including both embryonic stem cells (ESCs) and induced pluripotent stem cells (iPSCs), in vitro and for delivering stem cells into the damaged nervous system in vivo [67-77]. Other groups have examined the behavior of MSCs seeded inside of fibrin clots and treated with growth factors for use in engineering bone. In terms of other applications, fibrin scaffolds seeded with stem cells have also been used for engineering cartilage $[78,79]$ and for promoting vasculature formation [80-82]. This body of work suggests that a variety of stem cell lines can be cultured inside of fibrin scaffolds for many different tissue engineering applications. While fibrin can be electrospun to generate scaffolds for cell culture, such scaffolds have not been evaluated for use in combination with stem cells for tissue engineering applications [83, 84], providing an interesting avenue for future work. Similarly, the use of fibrin microspheres seeded with stem cells also provides an opportunity for future investigation. Finally, hybrid bioinks containing fibrin have shown promise for 
use in 3D printing functional tissues from stem cells [85].

Silk

The secondary structure of silk can vary based on the source, but in general it tends to contain a number of $\beta$ sheets, giving it crystalline properties and relatively slow degradation rate in comparison to mammalian ECM proteins, such as fibrin and collagen [86]. Silk scaffolds can also be modified to enhance their chemical properties and enable controlled delivery of molecules $[87,88]$. The properties of silk make it attractive for engineering bone and ligament tissue [89]. Extensive research has been done using 3D silk scaffolds in conjunction with mesenchymal stem cells for these applications by David Kaplan's lab as well as others. [90-98]. Often these silk scaffolds are electrospun to improve their ability to form functional tissues from stem cells $[99,100]$.

Combining silk scaffolds with stem cells can produce replacements for damaged cartilage. Meinel and colleagues showed that silk scaffolds promoted more extensive chondrogenesis compared to collagen scaffolds when seeded with human mesenchymal stem cells [96]. More recent efforts have used the combination of stem cells with silk scaffolds to engineer skin as reviewed recently [101]. Silk offers superior biocompatibility in comparison to other biomaterials based on in vivo testing. An interesting study demonstrated that silk microspheres could be combined with a novel hydrogel as a novel injectable way to deliver cardiac-derived stem cells [102]. This study opens intriguing areas for future work. Silk has also recently been evaluated as a potential bioink [103], making the $3 \mathrm{D}$ printing stem cell-derived tissues possible.

\section{Laminin}

Laminin, a high molecular weight protein ranging in size from $\sim 400 \mathrm{kDa}-900 \mathrm{kDa}$, contains numerous sites for cell adhesion as it is found in the ECM [104]. It performs critical roles in several stem cell niches, including neural, cardiac, and kidney [105-107]. While laminin is not often used in 3D hydrogel form, it still can play a valuable role in controlling stem cell behavior. For example, laminin-coated surfaces support the maintenance and differentiation of stem cells [108]. Often times other scaffold materials are functionalized with laminin-derived peptides to enhance their ability to support stem cell adhesion and differentiation [109]. Similarly, electrospun scaffolds can be coated in different laminin fragments to enhance stem cell binding and differentiation [110, 111].
Further application of self-assembling lamininderived peptides will be discussed in the section on synthetic biomaterials.

\section{Fibronectin}

Another large glycoprotein found in the ECM is fibronectin, which contains sites for both cells and proteins to bind [112]. Fibronectin enhances the differentiation of neural stem cells into mature neural cells and it can serve as a scaffold for delivering stem cells into the damaged nervous system [113, 114]. It also plays an important role in chondrogenesis [115] and the loss of fibronectin correlates with decreased muscle regeneration capacity [116]. Another common strategy is to conjugate fibronectin or peptide motifs derived from fibronectin to functionalize scaffolds to enable them to bind stem cells for tissue engineering [117-119]. This strategy is often used to functionalize electrospun scaffolds produced from synthetic materials to enhance their bioadhesive properties, which enables them to support cell culture $[120,121]$. Thus, fibronectin serves as an important tool for engineering a variety of tissues from stem cells and it could serve as a valuable additive when developing novel bioinks for printing stem cells.

\section{Vitronectin}

Another glycoprotein vitronectin can be found in the serum and bone in addition to the ECM [122]. It often plays a role in tissue repair, including promoting angiogenesis after injury. Similar to laminin and fibronectin, vitronectin contains sites for integrins expressed by cells to bind, as well as sites for growth factors and other proteins to adhere [123]. Undifferentiated human pluripotent stem cells are often cultured on vitronectin surfaces as it provides a defined substrate in comparison with the traditionally used Matrigel (a mixture of proteins secreted by a mouse tumor cell line), reducing the possibility of immune response if these cells are transplanted into human subjects [123]. It also plays a role in promoting the differentiation of mesenchymal stem cells into osteoblasts, indicating its potential for stem cell applications [124]. While it tends not to be used as the sole scaffold material, other synthetic scaffolds have been decorated with vitronectin and its associated binding domains to produce engineered tissues from stem cells, including bone and neural tissue $[125,126]$. Similar to fibronectin, the addition of vitronectin enhances the ability of different types of scaffolds to bind and influence stem cell behavior. 


\section{Polysaccharide-based biomaterials}

Polysaccharides consist of sugar monomers, and these molecules perform important roles in maintaining the structure and function of the ECM. The structure and monomer composition contribute the properties of the specific polysaccharides. These polymers tend to be branched and they can be sourced from plants or animals. The source and method of isolation for a polysaccharide determines its level of immunogenicity and thus must be carefully chosen [127]. Polysaccharide-based scaffolds can often be formulated to gel rapidly, allowing for injection into the injury site - a desirable feature when engineering tissue and when delivering stem cells for clinical applications. Accordingly, these materials have been investigated for use as a potential scaffold material for stem cell transplantation. This section will review some of the most commonly used polysaccharide-based scaffolds, including agarose, alginate, hyaluronan, and chitosan, that have been used for the culture and differentiation of stem cells.

\section{Agarose}

Agarose, usually isolated from red algae and seaweed, consists of a galactose-based backbone and it possesses several desirable properties as a biomaterial for tissue engineering applications including being able to undergo reversible gelation in response to temperature [128]. The stiffness of agarose can be altered, allowing for tuning of the mechanical properties of the scaffold to specific tissue engineering applications [129]. Agarose hydrogels have been combined with stem cells for generating a variety of applications, including cartilage, heart, and nerve [130-134]. Bone and cartilage are commonly engineered by combining agarose with different types of stem cells. Stem cells can also be encapsulated into agarose microwells to form structures known as lockyballs where the interior of the structure consists of an aggregate of stem cells that is surrounded by a synthetic coating containing binding sites for other lockyballs. These lockyball structures can then be combined for tissue engineering applications as seen in Fig. 4 [135]. Finally, agarose can serve as a printable bioink with tunable properties for generating tissues from stem cells. Recent work illustrated how MSCs could be printed using an agarose-based bioink [136]. While some studies have explored electrospinning agarose fibers, these materials have not been evaluated in combination with stem cells [137]. In summary, agarose scaffolds and their different formulations provide a versatile platform for tissue engineering.

\section{Alginate}

The cell walls of brown algae contain the polysaccharide alginate, a popular biomaterial that is often used as a bioink for 3D printing tissues [138]. These properties also have led to its application for microencapsulation of stem cells as alginate can be ionically cross-linked, which can be used to expand and differentiate these stem cells into a variety of tissue types [139-142]. Similar to agarose, many studies have combined both adipose-derived adult stem cells (ASCs) as well as bone marrow-derived MSCs with alginate hydrogels to generate replacement cartilage [132, 143-145]. Alginate has also been used for neural tissue engineering applications with a variety of stem cell types [146, 147]. Tunable alginate scaffolds can be produced by incorporating enzyme releasing microspheres to control scaffold degradation and these scaffolds were successfully combined with neural stem cell progenitors to engineer neural tissues [148]. Alginate scaffolds have also been combined with ESCs to generate hepatocytes and vasculature $[149,150]$. While alginate can be electrospun, such scaffolds have not been evaluated for their compatibility with stem cells [151]. The properties of alginate make it easy to bioprint. Accordingly, several different 3D bioprinted tissues have been produced using alginate bioinks in combination with stem cells, including neural tissue, cartilage, bone and liver [152-155]. This body of work shows that alginate serves as a highly desirable material for engineering a wide variety of tissues due to its unique properties.

\section{Hyaluronan}

Hyaluronan, also known as hyaluronic acid, serves as one of the major components of the extracellular matrix, [156] containing numerous sites for cell adhesion [156]. Hyaluronan also plays a key role in various stem cell niches, suggesting its suitability as a scaffold material for stem cell culture [157]. The Langer lab demonstrated that such scaffolds could be used for promoting both self-renewal of human ES cells as well as vascular differentiation [158]. Also, a recent review detailed how different hyaluronan scaffolds can be combined with MSCs to engineer a variety of tissues, including cartilage and bone [159]. Work from the Woodhouse group has also used such approaches to engineer adipose substitutes from stem cells $[160,161]$. Other approaches 

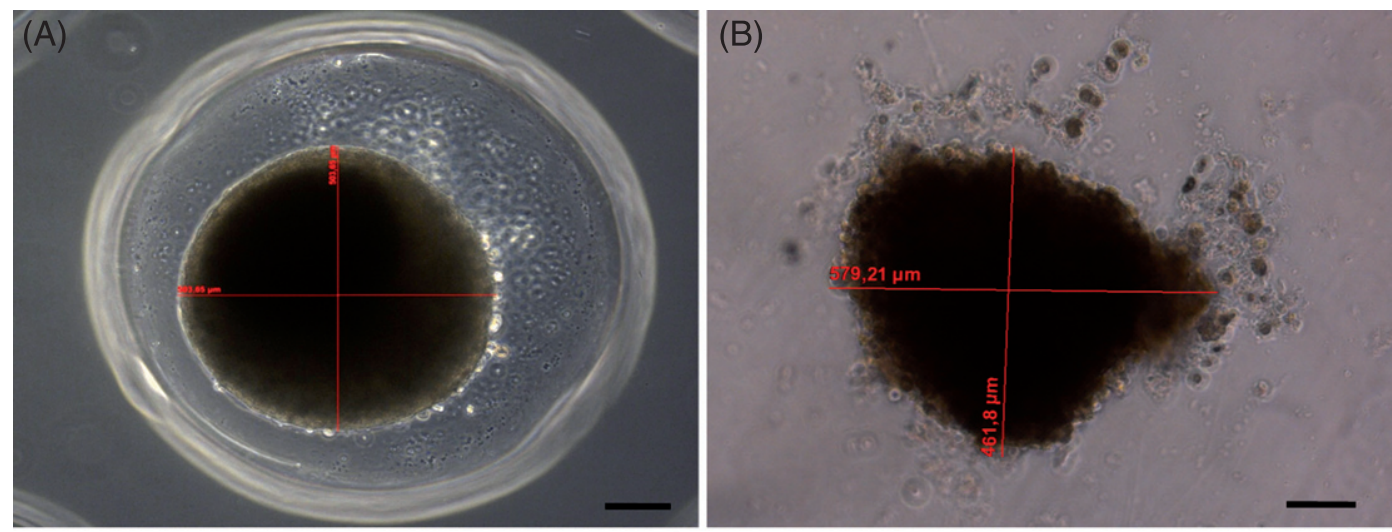

(C)

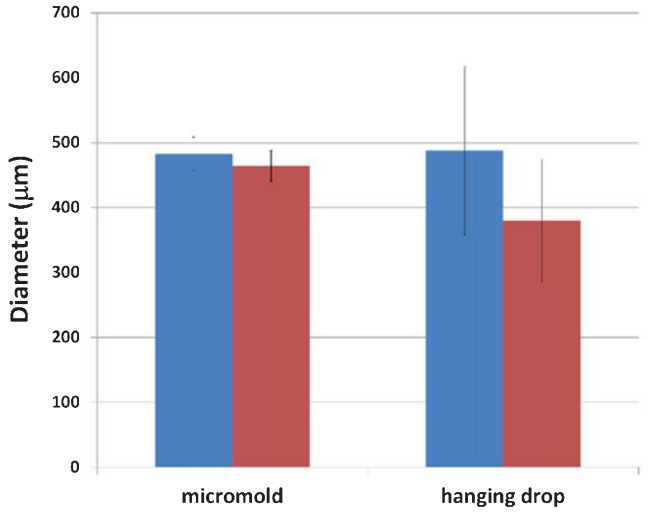

(D) 16

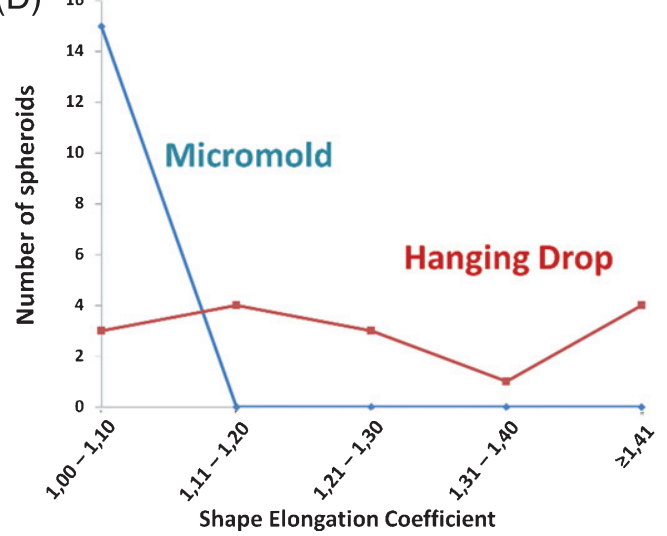

Fig. 4. Biofabrication of human adipose-derived stem cell (ASCs) spheroids. A) ASCs spheroid fabricated in a confined space (resection) of micro-molded non-adhesive hydrogel has more regular shape and size than B) ASCs spheroid fabricated by the hanging drop method. Phase contrast. Bar size: 100 micrometers. C) Graph showing major (blue bar) and minor (red bar) diameters of spheroids generated in hanging drop and in resections of micro-molded non-adhesive hydrogel. Note that standard deviation in hanging drops is higher. A total of 45 spheroids were measured randomly. Graph represents the mean \pm standard error. D) Graph showing shape elongation coefficient (major/minor diameter of each spheroid) distribution of spheroids biofabricated by the two techniques representative from 1 micro-molded non-adhesive hydrogel and 1 petri-dish. (blue: spheroids fabricated in resections of micro-molded hydrogel; red: spheroids fabricated in hanging drops). This figure was reproduced under a Attribution 4.0 International (CC BY 4.0). Figure taken from [135].

have combined hyaluronan scaffolds with stem cells derived from keratinocytes and adipose for engineering skin and bone respectively $[162,163]$. Such engineered tissues can be used as novel ways to promote wound healing as well as for repairing damaged nerve tissues [164-166]. Encapsulating stem cells into hyaluronic acid microcarriers is another popular tissue engineering strategy due to its ability to provide a supportive environment for stem cell survival $[167,168]$. Similar to other polysaccharides, hyaluronic acid can be incorporated into electrospun scaffolds to improve their biocompatibility and enhance cell adhesion [169]. Finally, several recent studies have demonstrated that bioink formulations containing hyaluronic acid can be used to bioprint $3 \mathrm{D}$ tissues, making this an exciting area for future work [170-172].

\section{Chitosan}

Another commonly used polysaccharide, chitosan, can be derived by the deacetylation of chitin and it consists of glucosamine units [173]. Additionally, the rate of gelation of chitosan scaffolds can be controlled using $\mathrm{pH}$ [174] and the scaffold properties can also be modulated for stem cell applications through chemical cross-linking [175]. Chitosan has been evaluated extensively for tissue engineering applications, including in combination with stem cells. For example, 3D chitosan scaffolds containing coralline promoted osteogenic differentiation of mouse mesenchymal stem cells [176]. Two recent papers reviewed such efforts using different formulations of chitosan scaffolds for applications in developing replacement bone and cartilage [177, 178]. Other efforts have combined chitosan scaffolds 
with stem cells to treat spinal cord injury $[179,180]$ as well as wound healing [181]. Chitosan scaffolds have supported the culture of mouse ESCs and the expansion of cord blood-derived stem cells [182, 183]. Microencapsulation of MSCs inside of chitosan particles has also been evaluated as a way to engineer bone tissue engineering [184]. Chitosan and its derivatives can also be electrospun into substrates under the appropriate conditions [185]. Composite electrospun nanofibers containing chitosan support stem cell differentiation into nerve tissue, suggesting their utility for tissue engineering applications [186]. Chitosan can also be used as a bioink [187], but more work needs to be done to determine an optimal formulation for printing stem cell-derived constructs. Often these bioinks must be tailored to the specific application to ensure proper stem cell survival and differentiation.

\section{Cellulose and its derivatives}

Cellulose serves as a major component of cell walls found in bacteria and plants and it, along with its chemically modified derivatives, have been evaluated for tissue engineering applications [188]. It is often modified to enhance its ability to support mammalian cell culture. One of the most commonly used derivatives is methylcellulose due to its ability to form hydrogels under different conditions [189], including injectable versions and thermally reversible formulations [190]. These scaffold formulations can be combined with a number of stem cell types for engineering a wide variety of tissues, ranging from bone to nerve [191, 192]. It can also be combined with other polysaccharides to yield printable bioinks [172]. Cellulose and the closely related methylcellulose have demonstrated significant promise for a variety of tissue engineering applications due to its versatile properties.

\section{Decellularized extracellular matrix}

An alternative strategy to using pure biomaterials requires the process of removing the cellular components of a tissue, leaving behind the decellularized extracellular matrix (dECM) [193]. This method takes advantage of the natural bioactive properties of tissue to produce a suitable scaffold for stem cell culture and differentiation. The methods used to process the tissue may vary and can result in different properties for the scaffold material obtained [193] and they vary based on the tissue targeted [194]. Such dECM scaffolds have been extensively characterized for tissue engineering applications involving MSCs
[195, 196]. Even whole decellularized organs, such as kidneys and livers, can be repopulated into functional tissues after seeding with stem cells [197]. Such dECM materials can also be bioprinted, providing another avenue for tissue engineering [198]. While these materials show significant promise, they can show variability due to the source material and the isolation method, and could potentially trigger immune responses [199]. However, they are worthy of further investigation for applications in stem cell-based tissue engineering and potentially the engineering of whole organs.

\section{SYNTHETIC BIOMATERIALS}

Synthetic biomaterials provide an alternative to natural materials for engineering tissues from stem cells. These materials offer many advantages over their natural counterparts, including reproducibility due to their defined chemical composition, and the ability to control the mechanical properties, degradation rate, and shape independently. The mechanical properties of a scaffold play a large influence in how stem cells differentiate [200]. The ability to shape a material allows for production of scaffolds that conform to specifications of the injury or transplantation site. Producing scaffolds with a specific degradation rate serves as a key advantage of synthetic scaffolds over natural biomaterials, and they can also affect the release rate of drugs incorporated into such scaffolds. However, many synthetic biomaterials lack sites for cell adhesion and accordingly must be chemically modified to allow for stem cell adhesion and culture. Other considerations when choosing a biomaterial include the biocompatibility of the material and its suitability for transplantation in vivo, as well as whether the material and its byproducts can trigger an immune response. However, as the following section will attest - many synthetic materials demonstrate huge promise for stem cell-based tissue engineering.

\section{Polymer-based biomaterials}

This section discusses synthetic polymers and how they can be combined with stem cells for producing different tissues. These materials are chemically defined and can often be formulated to have targeted mechanical properties to replicate the microenvironment present in the tissue being engineered. They can also be chemically modified to contain cues to enhance their bioactivity and promote stem cell differentiation into the desired phenotypes. Potential 
issues with these polymers include a lack of sites for cell adhesion and the potential for toxic byproducts after degradation. This section focuses on the most commonly used polymer scaffolds for culture of stem cells and their different formulations.

\section{Poly (lactic-co-glycolic acid)}

Poly (lactic-co-glycolic acid) (PLGA) a copolymer that consists of monomers of glycolic acid and lactic acid connected by ester bonds, has been approved by the FDA for a range of applications, mainly focused on drug delivery as it can be formulated to control drug release rate [201]. Cells enzymatically degrade PLGA into monomers that can cause cell death due to their acidic nature [202]. PLGA can be formulated into scaffolds, nano and microparticles, and electrospun fibers [203]. The ability to create biocompatible scaffolds with tunable drug delivery properties makes PLGA an attractive material for stem cell-based tissue engineering.

PGLA scaffolds can be combined with different types of stem cells, including MSCs, ESCs, and iPSCs to engineer a wide range of tissues, including muscle, bone, cartilage, and nerve [204-209]. The scaffold porosity, topography, mechanical properties, and drug delivery capacity all serve as important variables when designing such scaffolds. Both PLGA microspheres and electrospun nanofibers have also been used for differentiating stem cells into mature tissue types as well [210, 211]. Intriguingly, despite its widespread adoption as a biomaterial for clinical applications as well as for engineering tissues in vitro, PLGA has not been adopted as a bioink for use with 3D printers. This knowledge gap provides an intriguing opportunity for further work.

\section{Poly (ethylene glycol)}

Poly (ethylene glycol) (PEG), and its high molecular weight counterpart poly (ethylene oxide) (PEO), resist protein absorption, making them a commonly used polymer for in vivo applications due to this biocompatibility [212]. Scaffolds made from PEG can be polymerized chemically or using photoinitiators. The amount of initiator used affects the properties of the resulting scaffolds and it also means PEG can be used for applications in 3D printing [213]. While unmodified PEG is typically inert, it can also be chemically modified to contain bioactive molecules, including peptides and heparin [214]. PEG hydrogel scaffolds have been combined with a variety of stem cell types for their suitability as potential replacements for bone, cartilage, nerve, liver and vasculature tissue [215-223]. Other groups have incorporated PEG into other polymer solutions for producing electrospun scaffolds for engineering tissues from stem cells [224, 225]. PEG microcarriers can also serve as effective vehicles for delivering stem cells for in vivo tissue engineering applications [226, 227]. More recent work has focused on using PEG-derived bioinks to print tissue constructs from stem cells, including cartilage and muscle tissues [228, 229]. Its versatility and ability to be modified make PEG an essential tool for tissue engineering.

\section{Poly (caprolactone) (PCL)}

Poly caprolactone (PCL), a popular low-cost polymer with an extended degradation rate, can be used to form a wide range of scaffolds with different properties, including novel topographies and controlled release, for applications in tissue engineering as reviewed recently [230]. These scaffolds are often fabricated using both solution and melt electrospinning, and then seeded with stem cells to engineer tissues, including cartilage, nerve, muscle, and bone [231-235]. Figure 5 shows an example of how such scaffolds can be combined with adipose-derived stem cells to produce fat tissue as well as how topographical cues can influence stem cell behavior [236]. Melt electrospinning requires that the PCL be heated until it becomes a liquid, which can then be used to directly write scaffolds with defined structures that can be seeded with cells [237]. Similar work has been performed using 3D printed PCL to produce defined structures which are then seeded with stem cells to engineer tissues such as bone [238]. Work still remains to create a PCL bioink that could directly print cells into defined structures. Other work has incorporated drug-releasing PCL microspheres in pluripotent stem cell aggregates to engineer neural tissues [239, 240]. Also, the mechanical stability and ability to generate controlled drug release over extended time periods means that PCL is often combined with other biomaterials to generate hybrid scaffolds for tissue engineering [241], making it a useful biomaterial for a range of applications.

\section{Polypyrrole (Ppy)}

Polypyrrole (Ppy) possess the unique property of being a biocompatible conductive polymer, which makes it attractive for certain tissue engineering applications such as nerve and muscle [242]. It can also be doped with biological molecules, including polysaccharides, such as heparin and hyaluronic acid, and such biomaterials have been used to engineer 


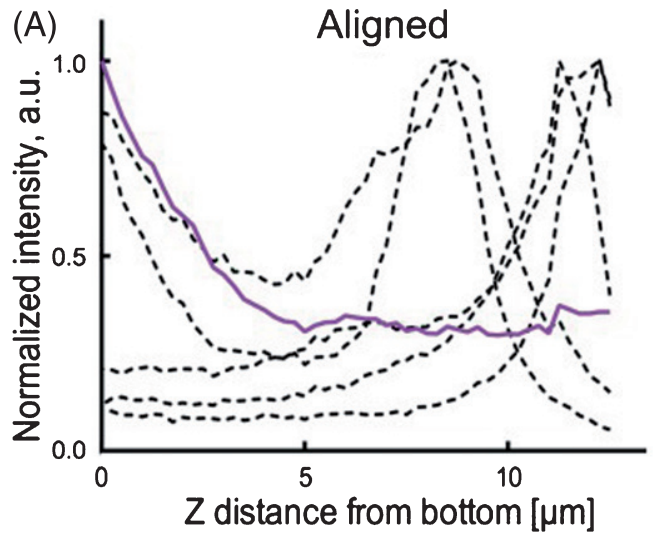

(B)

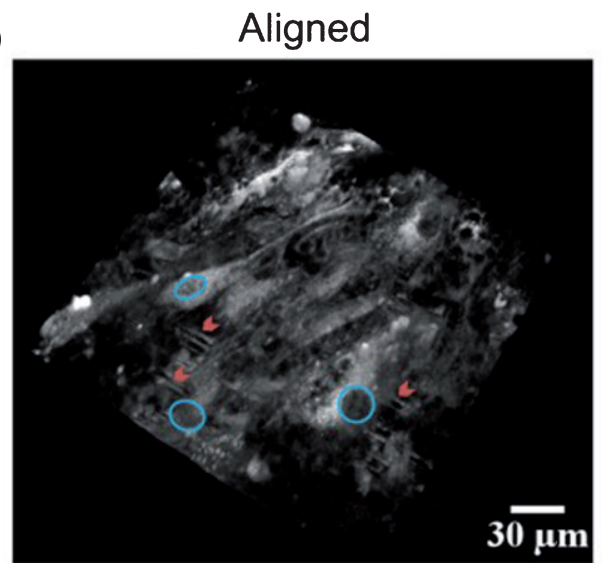

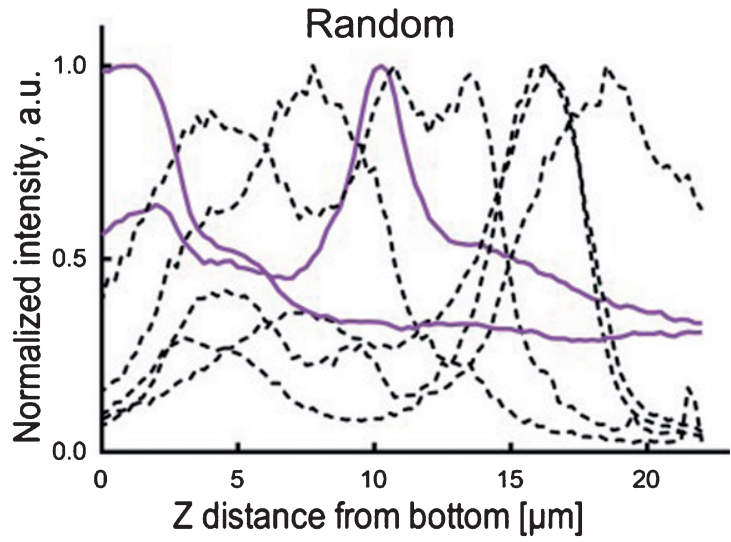

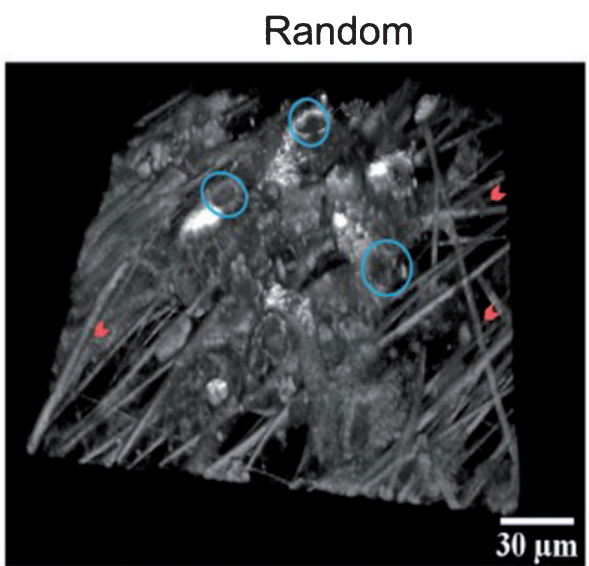

Fig. 5. Human adipose derived stem cells growing in PCL fiber matrices. A) Normalized intensities of the CARS (2845 cm-1) signal of the fibers (violet, solid) and the MPEF signal (495-530 nm) (black, dashed lines, one line for each cell) of the cells in the matrices in the $\mathrm{z}$ dimension for the aligned (left) and random (right) matrices. 5 cells were investigated for each condition, for the random matrix two fibers were shown to visualize the different fiber profiles in this matrix. B) 3D reconstructions of the MPEF signals of the cells on/in the fiber matrices for aligned (left) and random (right) matrices. Nuclei are indicated with circles and fibers with arrowheads (scalebar: $30 \mu \mathrm{m}$ ). This figure was reproduced under a Attribution 4.0 International (CC BY 4.0). Figure taken from [236].

bone from MSCs [243]. The use of electrical stimulation on stem cells seeded on Ppy scaffolds enhances their differentiation into neural tissue, including promoting the development of mature retinal cells [244] and neurons [244]. Electrical stimulation of stem cells seeded on Ppy scaffolds can also drive osteogenesis [245] and the formation of functional muscle tissues [246]. Ppy can also be electrospun to produce scaffolds for stem cell differentiation [247] as well as be combined with other materials to generate conductive hybrid scaffolds for stem cell-based tissue engineering [248].

\section{Polydimethylsiloxane (PDMS)}

Polydimethylsiloxane (PDMS), a silicon-based viscoelastic polymer, has been used in a wide range of biomedical applications due to its inertness [249]. It is often used to construct microfluidic devices, which serve as valuable tools for studying stem cell behavior [250]. Its inert nature makes an ideal material to create molds for replicating tissue structure, such as vasculature networks being derived from pluripotent stem cells [251] or for creating spheroids from different types of stem cells [252]. As a scaffold material, PDMS can be modified to contain chemical cues, including sites for cell adhesion. The mechanical properties of PDMS are easily manipulated and thus these scaffolds have been used to determine how mechanical properties of the microenvironment influence stem cell differentiation [200, 253]. Another interesting tissue engineering application requires the incorporation of PDMS microspheres in stem cell aggregates. Such microspheres can provide mechanoregulation cues to direct MSC differentiation into functional tissues [254]. Additionally, hybrid microparticles consisting of PDMS and PCL 
promoted ESCs to form cardiovascular tissue [255]. PDMS has been applied in unique ways to engineer tissues from stem cells as discussed here.

\section{Peptide-based biomaterials}

Peptide-based biomaterials consist of short sequences of amino acids, which can produce selfassembling scaffolds [256]. These scaffolds combine the functionality of protein-based scaffolds by using motifs derived from naturally occurring proteins with the reproducibility of synthetic scaffolds. Many of the peptide-based biomaterials can self-assemble into 3D scaffolds using amphiphilic peptides, which form aggregates in aqueous solutions. The Stupp lab was one of the first groups to use such self-assembling scaffolds for promoting the differentiation of murine neural progenitor cells into neurons [257]. These scaffolds contained the peptide sequence IKVAV (isoleucine-lysine-valine-alaninevaline) derived from laminin and this sequence had been shown previously to promote neurite outgrowth [258]. A similar approach was used to develop self-assembling peptide scaffolds seeded with mesenchymal stem cells for bone tissue engineering [259]. A variety of such self-assembling peptides have been evaluated for stem cell applications both in vitro and in vivo [260, 261]. Figure 6 shows representative images of different types of self-assembled

(A)

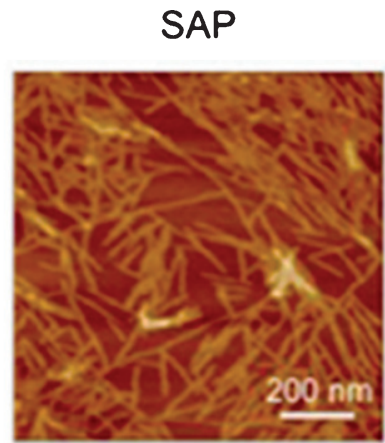

SAP-RGD

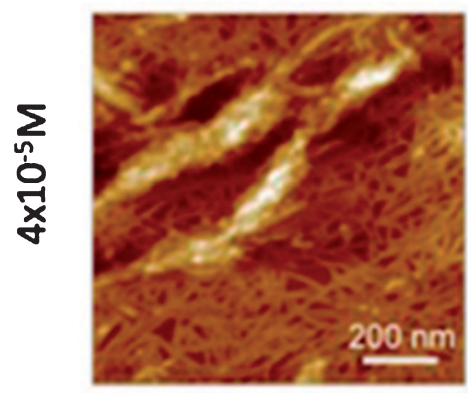

(B)

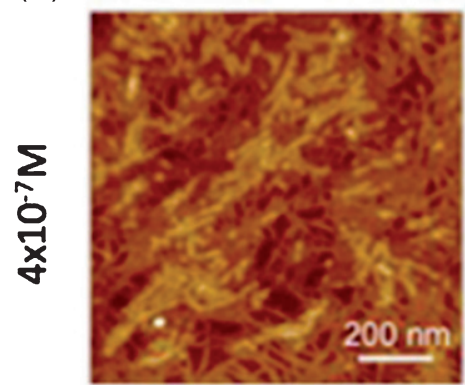

SAP-HVP
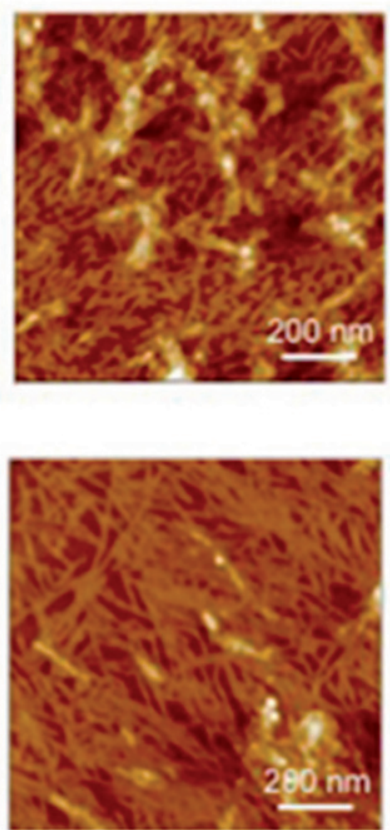

SAP-IGF-1
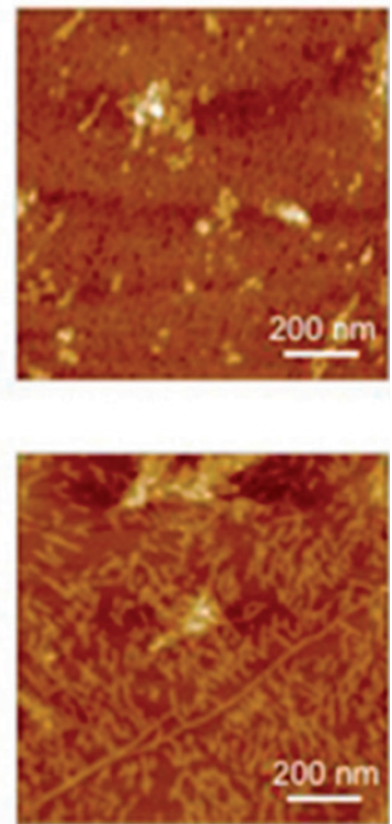

Fig. 6. Atomic Force Microscopy (AFM) images of: A) Self-assembling peptide hydrogel pristine (SAP) or enriched with conjugates between SAPs and adhesive peptides (called SAP-RGD and SAP-HVP) or decorated with a conjugate between SAP and Insulin-like Growth factor-1 (called SAP-IGF-1) at 4 10-5 M; and B) SAP-RGD, SAP-HVP and SAP-IGF-1 at 4 10-7 M on mica surface. This figure was reproduced under a Attribution 4.0 International (CC BY 4.0). Figure taken from [261]. 
peptide scaffolds as analyzed using atomic force microscopy.

One popular self-assembling peptide called RADA16-I has been combined with stem cells for tissue engineering applications. Such scaffolds were seeded with embryoid bodies derived from mouse ESCs in the presence of osteogenic medium to engineer bone tissue [262]. A follow-up study combined these self-assembling peptides with the ceramic hydroxyapatite, producing a more effective scaffold for differentiating the mouse ESCs seeded inside [263]. The Zhang lab altered the RADA16 sequence to incorporate 18 different peptide motifs to determine the most appropriate scaffold material for mouse adult neural stem cells [264]. More recent work has shown that RADA16 scaffolds can be combined with stem cells to engineer cardiac, neural, adipose and bone tissue [265-268]. As their properties can be modified based on changing their

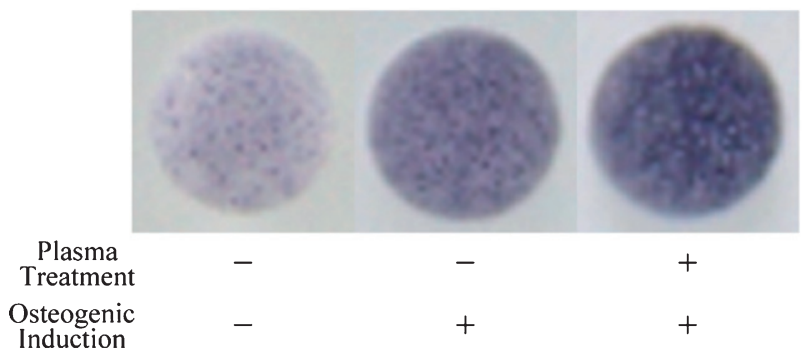

(C)

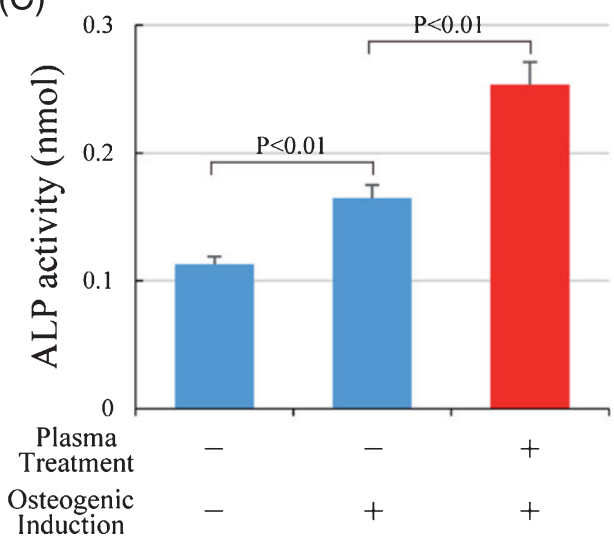

sequence, there are significant possibilities to extend such peptide scaffolds for a range of tissue engineering applications.

\section{CERAMIC-BASED BIOMATERIALS}

Ceramics, inorganic materials formed through treatment with heat, possess crystalline structures, meaning they are often porous and brittle [269]. Commonly used ceramics include bioactive glass, which consists of a mixture of silicon dioxide, sodium oxide, calcium oxide, and phosphate oxide, [270] and hydroxyapatite, a naturally occurring material found in bone [271]. Other ceramic-based materials exhibit similar properties and these materials, along with hydroxyapatite, have been investigated extensively in combination with stem cells for tissue engineering of bone [206, 272-289]. Figure 7

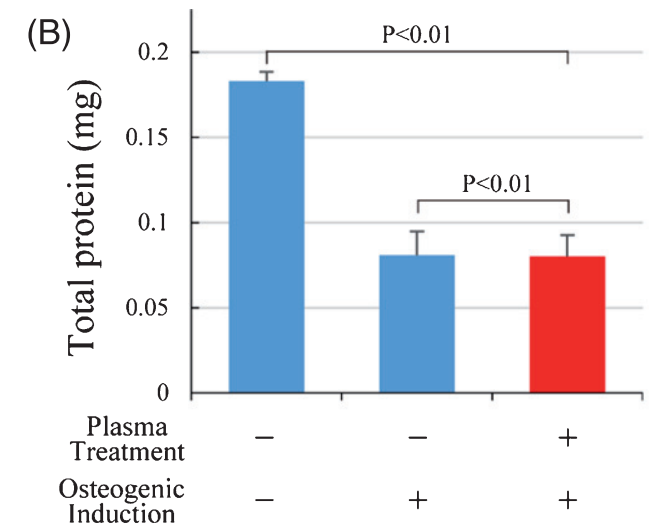

(D)

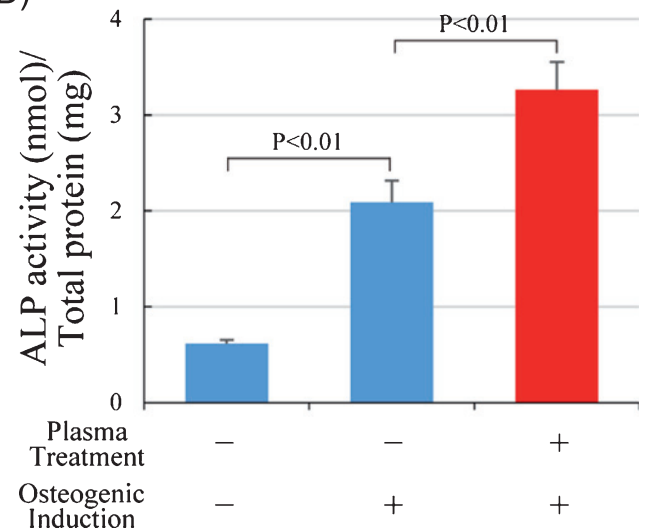

Fig. 7. In vitro osteogenesis of interconnected porous hydroxyapatite (IP-CHA discs combined with rat MSCs. A) Alkaline phosphatase (ALP) staining of IP-CHA discs, which were combined with MSCs and cultured in vitro for 14 days in non-osteogenic or osteogenic differentiation medium. Each graph is composed of three groups: no osteogenic induction (left), plasma-untreated (center), and plasmatreated (right) IP-CHA discs. ALP activity, B) and content of total protein, C) per MMCs/IP-CHA composite. D) ALP activity normalized by the content of total protein. Data were represented as mean \pm SD of 2 independent triplicate experiments. This figure reprinted under a Attribution 4.0 International (CC BY 4.0) license. Figure taken from [290]. 
shows an excellent example of how interconnected porous calcium hydroxyapatite (IP-CHA) scaffolds can direct MSCs to form bone tissue [290]. These studies include both in vitro and in vivo testing of these materials. The Caplan lab has done a great deal of work characterizing the culture of mesenchymal stem cells on ceramic materials as a way to engineer bone tissue [279, 283, 286]. Other groups as well have performed similar studies as reviewed recently [291]. These ceramic-based materials can be combined with biodegradable polymers, such as those materials mentioned earlier in this review, to be used for bone tissue engineering applications [292-294]. The use of composite materials allows for the ability to deliver drugs and the fabrication of highly porous structures necessary for stem cell infiltration when tissue engineering. More recent work has focused on how to use additive manufacturing to bioprint ceramic scaffolds and related composites for tissue engineering applications, which is an important area for future work [295].

\section{CONCLUSIONS AND FUTURE STUDIES}

This review detailed the most commonly used biomaterial scaffolds for engineering tissues from stem cells by covering the types of materials available and their unique properties. This information allows readers to determine which material best suits their specific application. As mentioned in earlier in this review, many of these materials have not been fully optimized for specific tissue engineering applications and further work will continue to optimize these formulations for translation to the clinic for targeted applications. For example, optimized scaffolds could enhance the survival and differentiation of neural stem cells being transplanted into the diseased or damaged nervous system, which could lead to improved function. The type of material and the cues that are incorporated in the scaffold play a large role in directing the fate of the stem cells seeded inside as detailed in this review. The ability to further functionalize the materials discussed in this review in terms of their mechanical and chemical properties provides an excellent opportunity for future work, as such bioactive and instructive scaffolds can improve cell survival and differentiation into the desired phenotypes. The method of fabrication serves as an important parameter, which allows different types of patterns and architecture to be formed, which include hydrogels, microcarriers, fibers and 3D bioprinted constructs. In particular, $3 \mathrm{D}$ bioprinting offers the possibility of printing constructs to fill an injury site as well as the ability to produce tissues with complex structures containing multiple cell types. Additionally, work remains to make many of these biomaterials into printable formulations that can support stem cell survival and differentiation post printing. being able to incorporate or produce a vascular network inside of engineered tissues fabricated through traditional tissue engineering methods as well as using bioprinting remains challenging, but may be addressed through complex $3 \mathrm{D}$ printing strategies or through other strategies. The lack of a stable vasculature often restricts the size of the constructs due to concerns about maintaining cell viability in light of diffusion constraints. This review provides an important overview of the general concepts when combining biomaterial scaffolds with stem cells for tissue engineering applications.

\section{ACKNOWLEDGMENTS}

Dr. Stephanie Willerth would like to acknowledge funding from the Canada Research Chairs program, the Natural Science and Engineering Research Council, the Stem Cell Network, and the British Columbia Innovation Council's Ignite Program. Dr. SakiyamaElbert would like to acknowledge funding from the NIH (NINDS R01 NS090617).

\section{DISCLOSURES}

Dr. Willerth has on-going a collaborative research agreement with Aspect Biosystems to commercialize her neural tissue engineering technologies and a collaborative research agreement with iProgen Biotech for her reprogramming work.

\section{STEMJOURNAL OPEN REVIEW}

The evaluations from reviewers for this article are freely available and can be found as supplementary material here: http://dx.doi.org/10.3233/STJ180001.

\section{REFERENCES}

[1] Willerth, SM, Sakiyama-Elbert SE. Combining stem cells and biomaterial scaffolds for constructing tissues and cell delivery (July 09, 2008), StemBook, ed. The Stem Cell Research Community, StemBook, doi/10.3824/stembook. 1.1.1, https://www.stembook.org. 
[2] Trounson A, McDonald C. Stem cell therapies in clinical trials: Progress and challenges. Cell Stem Cell. 2015; 17:11-22.

[3] Lanza R, Gearhart J, Hogan B, Melton D, Pedersen R, Thomas ED, Thomson JA, West M. Essentials of Stem Cell Biology, Elsevier. 2005.

[4] Takahashi K, Yamanaka S. Induction of pluripotent stem cells from mouse embryonic and adult fibroblast cultures by defined factors. Cell. 2006;126:663-76.

[5] Williams DF. Definitions in Biomaterials: Proceeding of a Consensus Conference of the European Society of Biomaterials, Chester, England, March 3-5, Elsevier, Amsterdam. 1987.

[6] Ahmed EM. Hydrogel: Preparation, characterization, and applications: A review. Journal of Advanced Research. 2015;6:105-21.

[7] Donaghue IE, Tam R, Sefton MV, Shoichet MS. Cell and biomolecule delivery for tissue repair and regeneration in the central nervous system. Journal of Controlled Release. 2014;190:219-27.

[8] Forte G. Adult stem cells and biocompatible scaffolds as smart drug delivery tools for cardiac tissue repair. Current Medicinal Chemistry. 2013;20:1.

[9] Guvendiren M, Burdick JA. Engineering synthetic hydrogel microenvironments to instruct stem cells. Current Opinion in Biotechnology. 2013;24:841-6.

[10] Zhang Z. Injectable biomaterials for stem cell delivery and tissue regeneration. Expert Opinion on Biological Therapy. 2017;17:49-62.

[11] Pal A, Vernon BL, Nikkhah M. Therapeutic neovascularization promoted by injectable hydrogels. Bioactive Materials. 2018;3:389-400

[12] Yan Z, Yin H, Nerlich M, Pfeifer CG, Docheva D. Boosting tendon repair: Interplay of cells, growth factors and scaffold-free and gel-based carriers. Journal of Experimental Orthopaedics. 2018;5:1.

[13] Jansen K, CL Schuurmans C, Jansen J, Masereeuw R, Vermonden T. Hydrogel-Based Cell Therapies for Kidney Regeneration: Current Trends in Biofabrication and In Vivo Repair. Current Pharmaceutical Design. 2017;23: 3845-57.

[14] Maclean FL, Rodriguez AL, Parish CL, Williams RJ, Nisbet DR. Integrating biomaterials and stem cells for neural regeneration. Stem Cells and Development. 2015;25: 214-26.

[15] Uyar T, Kny E. Electrospun materials for tissue engineering and biomedical applications: Research, design and commercialization, Woodhead Publishing. 2017.

[16] Deitzel JM, Kleinmeyer J, Harris D, Tan NB. The effect of processing variables on the morphology of electrospun nanofibers and textiles. Polymer. 2001;42:261-72.

[17] Sankar S, Sharma CS, Rath SN, Ramakrishna S. Electrospun fibers for recruitment and differentiation of stem cells in regenerative medicine. Biotechnology Journal. 2017;12(12):1-11

[18] Nguyen AT, Sathe SR, Yim EK. From nano to micro: Topographical scale and its impact on cell adhesion, morphology and contact guidance. Journal of Physics: Condensed Matter. 2016;28:183001

[19] Luna JI, Ciriza J, Garcia-Ojeda ME, Kong M, Herren A, Lieu DK, Li RA, Fowlkes CC, Khine M, McCloskey KE. Multiscale biomimetic topography for the alignment of neonatal and embryonic stem cell-derived heart cells. Tissue Engineering Part C: Methods. 2011;17: 579-88.
[20] Newman P, Niño JLG, Graney P, Razal JM, Minett AI, Ribas J, Ovalle-Robles R, Biro M, Zreiqat H. Relationship between nanotopographical alignment and stem cell fate with live imaging and shape analysis. Scientific Reports. 2016;6:37909.

[21] Xie J, Willerth SM, Li X, Macewan MR, Rader A, Sakiyama-Elbert SE, Xia Y. The differentiation of embryonic stem cells seeded on electrospun nanofibers into neural lineages. Biomaterials. 2009;30:354-62.

[22] Briggs T, Arinzeh TL. Examining the formulation of emulsion electrospinning for improving the release of bioactive proteins from electrospun fibers. Journal of Biomedical Materials Research Part A. 2014;102:674-84.

[23] Lu Y, Huang J, Yu G, Cardenas R, Wei S, Wujcik EK, Guo Z. Coaxial electrospun fibers: Applications in drug delivery and tissue engineering. Wiley Interdisciplinary Reviews: Nanomedicine and Nanobiotechnology. 2016;8: 654-77.

[24] De Jong WH, Borm PJ. Drug delivery and nanoparticles: Applications and hazards. International Journal of Nanomedicine. 2008;3:133.

[25] Kohane DS. Microparticles and nanoparticles for drug delivery. Biotechnology and Bioengineering. 2007;96: 203-9.

[26] Saraiva C, Praça C, Ferreira R, Santos T, Ferreira L, Bernardino L. Nanoparticle-mediated brain drug delivery: Overcoming blood-brain barrier to treat neurodegenerative diseases. Journal of Controlled Release. 2016;235: 34-47.

[27] Thoniyot P, Tan MJ, Karim AA, Young DJ, Loh XJ. Nanoparticle-hydrogel composites: Concept, design, and applications of these promising, multi-functional materials. Advanced Science. 2015;2.

[28] Ji W, Sun Y, Yang F, van den Beucken JJ, Fan M, Chen $\mathrm{Z}$, Jansen JA. Bioactive electrospun scaffolds delivering growth factors and genes for tissue engineering applications. Pharmaceutical Research. 2011;28:1259-72.

[29] Labriola NR, Azagury A, Gutierrez R, Mathiowitz E, Darling EM. Concise Review: Fabrication, Customization, and Application of Cell Mimicking Microparticles in Stem Cell Science. Stem Cells Translational Medicine. 2018.

[30] Bratt-Leal AM, Carpenedo RL, McDevitt TC. Engineering the embryoid body microenvironment to direct embryonic stem cell differentiation. Biotechnology Progress. 2009;25:43-51.

[31] Parenteau-Bareil R, Gauvin R, Berthod F. Collagen-based biomaterials for tissue engineering applications. Materials. 2010;3:1863-87.

[32] Antoine EE, Vlachos PP, Rylander MN. Review of collagen I hydrogels for bioengineered tissue microenvironments: Characterization of mechanics, structure, and transport. Tissue Engineering Part B: Reviews. 2014;20:683-96.

[33] Zhu J, Marchant RE. Design properties of hydrogel tissueengineering scaffolds. Expert Review of Medical Devices. 2011;8:607-26.

[34] Chen SS, Revoltella RP, Papini S, Michelini M, Fitzgerald W, Zimmerberg J, Margolis L. Multilineage differentiation of rhesus monkey embryonic stem cells in threedimensional culture systems. Stem Cells. 2003;21:281-95.

[35] Gerecht-Nir S, Ziskind A, Cohen S, Itskovitz-Eldor J. Human embryonic stem cells as an in vitro model for human vascular development and the induction of vascular differentiation. Lab Invest. 2003;83:1811-20. 
[36] Ma W, Fitzgerald W, Liu QY, O’Shaughnessy TJ, Maric D, Lin HJ, Alkon DL, Barker JL. CNS stem and progenitor cell differentiation into functional neuronal circuits in three-dimensional collagen gels. Exp Neurol. 2004; 190:276-88.

[37] Battista S, Guarnieri D, Borselli C, Zeppetelli S, Borzacchiello A, Mayol L, Gerbasio D, Keene DR, Ambrosio L, Netti PA. The effect of matrix composition of 3D constructs on embryonic stem cell differentiation. Biomaterials. 2005;26:6194-207.

[38] Baharvand H, Hashemi SM, Kazemi Ashtiani S, Farrokhi A. Differentiation of human embryonic stem cells into hepatocytes in 2D and 3D culture systems in vitro. Int J Dev Biol. 2006;50:645-52.

[39] O'Connor SM, Stenger DA, Shaffer KM, Maric D, Barker $\mathrm{JL}$, Ma W. Primary neural precursor cell expansion, differentiation and cytosolic $\mathrm{Ca}(2+)$ response in threedimensional collagen gel. J Neurosci Methods. 2000;102: 187-95.

[40] Watanabe K, Nakamura M, Okano H, Toyama Y. Establishment of three-dimensional culture of neural stem/progenitor cells in collagen Type-1 Gel. Restor Neurol Neurosci. 2007;25:109-17.

[41] Daya S, Loughlin AJ, Macqueen HA. Culture and differentiation of preadipocytes in two-dimensional and threedimensional in vitro systems. Differentiation. 2007;75: 360-70.

[42] Chan BP, Hui TY, Yeung CW, Li J, Mo I, Chan GC. Self-assembled collagen-human mesenchymal stem cell microspheres for regenerative medicine. Biomaterials. 2007;28:4652-66.

[43] Noth U, Schupp K, Heymer A, Kall S, Jakob F, Schutze N, Baumann B, Barthel T, Eulert J, Hendrich C. Anterior cruciate ligament constructs fabricated from human mesenchymal stem cells in a collagen type I hydrogel. Cytotherapy. 2005;7:447-55.

[44] Sumanasinghe RD, Bernacki SH, Loboa EG. Osteogenic differentiation of human mesenchymal stem cells in collagen matrices: Effect of uniaxial cyclic tensile strain on bone morphogenetic protein (BMP-2) mRNA expression. Tissue Eng. 2006;12:3459-65.

[45] Yue K, Trujillo-de Santiago G, Alvarez MM, Tamayol A, Annabi N, Khademhosseini A. Synthesis, properties, and biomedical applications of gelatin methacryloyl (GelMA) hydrogels. Biomaterials. 2015;73:254-71.

[46] Klotz BJ, Gawlitta D, Rosenberg AJ, Malda J, Melchels FP. Gelatin-methacryloyl hydrogels: Towards biofabrication-based tissue repair. Trends in Biotechnology. 2016;34:394-407.

[47] Zhu W, Harris BT, Zhang LG. In Engineering in Medicine and Biology Society (EMBC), 2016 IEEE 38th Annual International Conference of the IEEE, 2016, pp. 4185-8.

[48] Levato R, Webb WR, Otto IA, Mensinga A, Zhang Y, van Rijen M, van Weeren R, Khan IM, Malda J. The bio in the ink: Cartilage regeneration with bioprintable hydrogels and articular cartilage-derived progenitor cells. Acta Biomaterialia. 2017;61:41-53.

[49] Stratesteffen H, Köpf M, Kreimendahl F, Blaeser A, Jockenhoevel S, Fischer H. GelMA-collagen blends enable drop-on-demand 3D printablility and promote angiogenesis. Biofabrication. 2017;9:045002.

[50] Dolatshahi-Pirouz A, Nikkhah M, Gaharwar AK, Hashmi B, Guermani E, Aliabadi H, Camci-Unal G, Ferrante T, Foss M, Ingber DE. A combinatorial cell-laden gel microarray for inducing osteogenic differentiation of human mesenchymal stem cells. Scientific Reports. 2014; 4:3896.

[51] Walters BD, Stegemann JP. Strategies for directing the structure and function of three-dimensional collagen biomaterials across length scales. Acta Biomaterialia. 2014;10:1488-501.

[52] Sajkiewicz P, Kołbuk D. Electrospinning of gelatin for tissue engineering-molecular conformation as one of the overlooked problems. Journal of Biomaterials Science, Polymer Edition. 2014;25:2009-22.

[53] Sell SA, McClure MJ, Garg K, Wolfe PS, Bowlin GL. Electrospinning of collagen/biopolymers for regenerative medicine and cardiovascular tissue engineering. Advanced Drug Delivery Reviews. 2009;61:1007-19.

[54] Sharif S, Ai J, Azami M, Verdi J, Atlasi MA, Shirian S, Samadikuchaksaraei A. Collagen-coated nanoelectrospun PCL seeded with human endometrial stem cells for skin tissue engineering applications. Journal of Biomedical Materials Research Part B: Applied Biomaterials. 2017.

[55] Yin H, Wang J, Gu Z, Feng W, Gao M, Wu Y, Zheng H, He $X, M o X$. Evaluation of the potential of kartogenin encapsulated poly (L-lactic acid-co-caprolactone)/collagen nanofibers for tracheal cartilage regeneration. Journal of Biomaterials Applications. 2017;32:331-41.

[56] Chan BP, Hui TY, Wong MY, Yip KHK, Chan GCF. Mesenchymal stem cell-encapsulated collagen microspheres for bone tissue engineering. Tissue Engineering Part C: Methods. 2009;16:225-35

[57] Li YY, Diao HJ, Chik TK, Chow CT, An XM, Leung V, Cheung KMC, Chan BP. Delivering mesenchymal stem cells in collagen microsphere carriers to rabbit degenerative disc: Reduced risk of osteophyte formation. Tissue Engineering Part A. 2014;20:1379-91.

[58] Yao L, Phan F, Li Y. Collagen microsphere serving as a cell carrier supports oligodendrocyte progenitor cell growth and differentiation for neurite myelination in vitro. Stem Cell Research \& Therapy. 2013;4:109.

[59] Zhao X, Liu S, Yildirimer L, Zhao H, Ding R, Wang H, Cui W, Weitz D. Injectable stem cell-laden photocrosslinkable microspheres fabricated using microfluidics for rapid generation of osteogenic tissue constructs. Advanced Functional Materials. 2016;26:2809-19.

[60] Ahmed TA, Dare EV, Hincke M. Fibrin: A versatile scaffold for tissue engineering applications. Tissue Engineering Part B: Reviews. 2008;14:199-215.

[61] Wiegner R, Chakraborty S, Huber-Lang M. Complementcoagulation crosstalk on cellular and artificial surfaces. Immunobiology. 2016;221:1073-9.

[62] Spotnitz WD. Fibrin sealant: The only approved hemostat, sealant, and adhesive - a laboratory and clinical perspective. ISRN surgery. 2014; 2014.

[63] Caliari SR, Burdick JA. A practical guide to hydrogels for cell culture. Nature Methods. 2016;13:405.

[64] Sreerekha P, Menon D, Nair S, Chennazhi K. Fabrication of fibrin based electrospun multiscale composite scaffold for tissue engineering applications. Journal of Biomedical Nanotechnology. 2013;9:790-800.

[65] Gorodetsky R. The use of fibrin based matrices and fibrin microbeads. FMB; for cell based tissue regeneration. Expert Opinion on Biological Therapy. 2008;8:1831-46.

[66] Robinson M, Douglas S, Willerth SM. Mechanically stable fibrin scaffolds promote viability and induce neurite outgrowth in neural aggregates derived from human induced pluripotent stem cells. Scientific Reports. 2017;7:6250. 
[67] Willerth SM, Arendas KJ, Gottlieb DI, Sakiyama-Elbert SE. Optimization of fibrin scaffolds for differentiation of murine embryonic stem cells into neural lineage cells. Biomaterials. 2006;27:5990-6003.

[68] Willerth SM, Faxel TE, Gottlieb DI, Sakiyama-Elbert SE. The effects of soluble growth factors on embryonic stem cell differentiation inside of fibrin scaffolds. Stem Cells. 2007;25:2235-44.

[69] Johnson PJ, Tatara A, Shiu A, Sakiyama-Elbert SE. Controlled release of neurotrophin-3 and platelet-derived growth factor from fibrin scaffolds containing neural progenitor cells enhances survival and differentiation into neurons in a subacute model of SCI. Cell Transplantation. 2010;19:89-101.

[70] Willerth SM, Rader A, Sakiyama-Elbert SE. The effect of controlled growth factor delivery on embryonic stem cell differentiation inside fibrin scaffolds. Stem Cell Research. 2008;1:205-18.

[71] Kolehmainen K, Willerth SM. Preparation of 3D fibrin scaffolds for stem cell culture applications. Journal of Visualized Experiments: JoVE. 2012.

[72] Montgomery A, Wong A, Gabers N, Willerth SM. Engineering personalized neural tissue by combining induced pluripotent stem cells with fibrin scaffolds. Biomaterials Science. 2015;3:401-13.

[73] Robinson M, Yau S-Y, Sun L, Gabers N, Bibault E, Christie BR, Willerth SM. Optimizing Differentiation Protocols for Producing Dopaminergic Neurons from Human Induced Pluripotent Stem Cells for Tissue Engineering Applications: Supplementary Issue: Stem Cell Biology. Biomarker Insights. 2015;10, BMI. S20064.

[74] Edgar JM, Robinson M, Willerth SM. Fibrin hydrogels induce mixed dorsal/ventral spinal neuron identities during differentiation of human induced pluripotent stem cells. Acta Biomaterialia. 2017;51:237-45.

[75] Lu P, Wang Y, Graham L, McHale K, Gao M, Wu D, Brock J, Blesch A, Rosenzweig ES, Havton LA. Long-distance growth and connectivity of neural stem cells after severe spinal cord injury. Cell. 2012;150:1264-73.

[76] Sharp KG, Yee KM, Steward O. A re-assessment of long distance growth and connectivity of neural stem cells after severe spinal cord injury. Experimental Neurology. 2014;257:186-204.

[77] Bento AR, Quelhas P, Oliveira MJ, Pêgo AP, Amaral IF. Three-dimensional culture of single embryonic stem-derived neural/stem progenitor cells in fibrin hydrogels: Neuronal network formation and matrix remodelling. Journal of Tissue Engineering and Regenerative Medicine. 2017;11:3494-507.

[78] Im GI, Shin YW, Lee KB. Do adipose tissue-derived mesenchymal stem cells have the same osteogenic and chondrogenic potential as bone marrow-derived cells? Osteoarthritis Cartilage. 2005;13:845-53.

[79] Worster AA, Brower-Toland BD, Fortier LA, Bent SJ, Williams J, Nixon AJ. Chondrocytic differentiation of mesenchymal stem cells sequentially exposed to transforming growth factor-beta1 in monolayer and insulin-like growth factor-I in a three-dimensional matrix. J Orthop Res. 2001;19:738-49.

[80] Liu H, Collins SF, Suggs LJ. Three-dimensional culture for expansion and differentiation of mouse embryonic stem cells. Biomaterials. 2006;27:6004-14.

[81] Arulmoli J, Wright HJ, Phan DT, Sheth U, Que RA, Botten GA, Keating M, Botvinick EL, Pathak MM, Zarembinski TI. Combination scaffolds of salmon fibrin, hyaluronic acid, and laminin for human neural stem cell and vascular tissue engineering. Acta Biomaterialia. 2016;43: 122-38.

[82] Almeida H, Eswaramoorthy R, Cunniffe G, Buckley C, O'Brien F, Kelly D. Fibrin hydrogels functionalized with cartilage extracellular matrix and incorporating freshly isolated stromal cells as an injectable for cartilage regeneration. Acta Biomaterialia. 2016;36:55-62.

[83] Gilbert-Honick J, Iyer SR, Somers SM, Lovering RM, Wagner K, Mao H-Q, Grayson WL. Engineering functional and histological regeneration of vascularized skeletal muscle. Biomaterials. 2018;164:70-9.

[84] Barreto-Ortiz SF, Zhang S, Davenport M, Fradkin J, Ginn B, Mao H-Q, Gerecht S. A novel in vitro model for microvasculature reveals regulation of circumferential ECM organization by curvature. PloS one. 2013;8:e81061.

[85] Hakam MS, Imani R, Abolfathi N, Fakhrzadeh H, Sharifi AM. Evaluation of fibrin-gelatin hydrogel as biopaper for application in skin bioprinting: An in-vitro study. BioMedical Materials and Engineering. 2016;27:669-82.

[86] Cao Y, Wang B. Biodegradation of silk biomaterials. International Journal of Molecular Sciences. 2009;10:1514-24.

[87] Li AB, Kluge JA, Guziewicz NA, Omenetto FG, Kaplan DL. Silk-based stabilization of biomacromolecules. Journal of Controlled Release. 2015;219:416-30.

[88] Yucel T, Lovett ML, Kaplan DL. Silk-based biomaterials for sustained drug delivery. Journal of Controlled Release. 2014;190:381-97.

[89] Melke J, Midha S, Ghosh S, Ito K, Hofmann S. Silk fibroin as biomaterial for bone tissue engineering. Acta Biomaterialia. 2016;31:1-16.

[90] Altman GH, Horan RL, Lu HH, Moreau J, Martin I, Richmond JC, Kaplan DL. Silk matrix for tissue engineered anterior cruciate ligaments. Biomaterials. 2002;23: 4131-41.

[91] Hofmann S, Hagenmuller H, Koch AM, Muller R, VunjakNovakovic G, Kaplan DL, Merkle HP, Meinel L. Control of in vitro tissue-engineered bone-like structures using human mesenchymal stem cells and porous silk scaffolds. Biomaterials. 2007;28:1152-62.

[92] Hofmann S, Knecht S, Langer R, Kaplan DL, VunjakNovakovic G, Merkle HP, Meinel L. Cartilage-like tissue engineering using silk scaffolds and mesenchymal stem cells. Tissue Eng. 2006;12:2729-38.

[93] Kim HJ, Kim UJ, Vunjak-Novakovic G, Min BH, Kaplan DL. Influence of macroporous protein scaffolds on bone tissue engineering from bone marrow stem cells. Biomaterials. 2005;26:4442-52.

[94] Mauney JR, Nguyen T, Gillen K, Kirker-Head C, Gimble JM, Kaplan DL. Engineering adipose-like tissue in vitro and in vivo utilizing human bone marrow and adiposederived mesenchymal stem cells with silk fibroin 3D scaffolds. Biomaterials. 2007;28:5280-90.

[95] Meinel L, Fajardo R, Hofmann S, Langer R, Chen J, Snyder B, Vunjak-Novakovic G, Kaplan D. Silk implants for the healing of critical size bone defects. Bone. 2005;37:688-98.

[96] Meinel L, Hofmann S, Karageorgiou V, Zichner L, Langer R, Kaplan D, Vunjak-Novakovic G. Engineering cartilage-like tissue using human mesenchymal stem cells and silk protein scaffolds. Biotechnol Bioeng. 2004;88: 379-91.

[97] Meinel L, Karageorgiou V, Fajardo R, Snyder B, Shinde-Patil V, Zichner L, Kaplan D, Langer R, VunjakNovakovic G. Bone tissue engineering using human 
mesenchymal stem cells: Effects of scaffold material and medium flow. Ann Biomed Eng. 2004;32:112-22.

[98] Meinel L, Karageorgiou V, Hofmann S, Fajardo R, Snyder B, Li C, Zichner L, Langer R, Vunjak-Novakovic G, Kaplan DL. Engineering bone-like tissue in vitro using human bone marrow stem cells and silk scaffolds. J Biomed Mater Res A. 2004;71:25-34.

[99] Ko E, Lee JS, Kim H, Yang SY, Yang D, Yang K, Lee J, Shin J, Yang HS, Ryu W. Electrospun Silk Fibroin Nanofibrous Scaffolds with Two-Stage Hydroxyapatite Functionalization for Enhancing the Osteogenic Differentiation of Human Adipose-Derived Mesenchymal Stem Cells. ACS Applied Materials \& Interfaces. 2017;10(9):7614-625.

[100] Li H, Wen F, Chen H, Pal M, Lai Y, Zhao AZ, Tan LP. Micropatterning extracellular matrix proteins on electrospun fibrous substrate promote human mesenchymal stem cell differentiation toward neurogenic lineage. ACS Applied Materials \& Interfaces. 2015;8: 563-73.

[101] Reimers K, Liebsch C, Radtke C, Kuhbier JW, Vogt PM. Silks as scaffolds for skin reconstruction. Biotechnology and Bioengineering. 2015;112:2201-5.

[102] Ciocci M, Cacciotti I, Seliktar D, Melino S. Injectable silk fibroin hydrogels functionalized with microspheres as adult stem cells-carrier systems. International Journal of Biological Macromolecules. 2017.

[103] Zheng Z, Wu J, Liu M, Wang H, Li C, Rodriguez MJ, Li G, Wang X, Kaplan DL. 3D Bioprinting of Self-Standing Silk-Based Bioink. Advanced healthcare materials. 2018.

[104] Yamada M, Sekiguchi K. Molecular basis of Laminin-Integrin Interactions In Current topics in membranes Elsevier, 2015, pp. 197-229.

[105] Theocharidis U, Long K, Faissner A. Regulation of the neural stem cell compartment by extracellular matrix constituents In Progress in brain research Elsevier, 2014, pp. 3-28.

[106] Carpino G, Renzi A, Franchitto A, Cardinale V, Onori P, Reid L, Alvaro D, Gaudio E. Stem/progenitor cell niches involved in hepatic and biliary regeneration. Stem Cells International. 2016.

[107] Perea-Gil I, Prat-Vidal C, Bayes-Genis A. In vivo experience with natural scaffolds for myocardial infarction: The times they are a-changin'. Stem cell Research \& Therapy. 2015;6:248.

[108] Polisetti N, Sorokin L, Okumura N, Koizumi N, Kinoshita S, Kruse FE, Schlötzer-Schrehardt U. Laminin-511 and-521-based matrices for efficient ex vivo-expansion of human limbal epithelial progenitor cells. Scientific Reports. 2017;7:5152.

[109] Negah SS, Khooei A, Samini F, Gorji A. Laminin-derived Ile-Lys-Val-ala-Val: A promising bioactive peptide in neural tissue engineering in traumatic brain injury. Cell and Tissue Research. 2017;1-14.

[110] Neal RA, Lenz SM, Wang T, Abebayehu D, Brooks BP, Ogle RC, Botchwey EA. Laminin-and basement membranepolycaprolactone blend nanofibers as a scaffold for regenerative medicine. Nanomaterials and the Environment. 2014;2.

[111] Hadjizadeh A, Savoji H, Ajji A. A Facile Approach for the Mass Production of Submicro/Micro Poly (Lactic Acid) Fibrous Mats and Their Cytotoxicity Test towards Neural Stem Cells. BioMed Research International. 2016.

[112] Zollinger AJ, Smith ML. Fibronectin, the extracellular glue. Matrix Biology. 2017;60:27-37.
[113] Rogers SL, Letourneau PC, Pech IV. The role of fibronectin in neural development. Developmental Neuroscience. 1989;11:248-65.

[114] Tate CC, Shear DA, Tate MC, Archer DR, Stein DG, LaPlaca MC. Laminin and fibronectin scaffolds enhance neural stem cell transplantation into the injured brain. Journal of Tissue Engineering and Regenerative Medicine. 2009;3:208-17.

[115] Singh P, Schwarzbauer JE. Fibronectin and stem cell differentiation-lessons from chondrogenesis. J Cell Sci. 2012;125:3703-12.

[116] Lukjanenko L, Jung MJ, Hegde N, Perruisseau-Carrier C, Migliavacca E, Rozo M, Karaz S, Jacot G, Schmidt $\mathrm{M}, \mathrm{Li} \mathrm{L}$. Loss of fibronectin from the aged stem cell niche affects the regenerative capacity of skeletal muscle in mice. Nature Medicine. 2016;22:897.

[117] Dubey G, Mequanint K. Conjugation of fibronectin onto three-dimensional porous scaffolds for vascular tissue engineering applications. Acta Biomaterialia. 2011;7:1114-25.

[118] Gonzalez-Perez F, Hernández J, Heimann C, Phillips JB, Udina E, Navarro X. Schwann cells and mesenchymal stem cells in laminin-or fibronectin-aligned matrices and regeneration across a critical size defect of $15 \mathrm{~mm}$ in the rat sciatic nerve. Journal of Neurosurgery: Spine. 2017;1-10.

[119] Sana FA, Yurtsever MÇ, Bayrak GK, Tunçay EÖ, Kiremitçi AS, Gümüşderelioğlu M. Spreading, proliferation and differentiation of human dental pulp stem cells on chitosan scaffolds immobilized with RGD or fibronectin. Cytotechnology. 2017;69:617-30.

[120] Regis S, Youssefian S, Jassal M, Phaneuf MD, Rahbar N, Bhowmick S. Fibronectin adsorption on functionalized electrospun polycaprolactone scaffolds: Experimental and molecular dynamics studies. Journal of Biomedical Materials Research Part A. 2014;102:1697-706.

[121] Campos DM, Gritsch K, Salles V, Attik GN, Grosgogeat B. Surface entrapment of fibronectin on electrospun PLGA scaffolds for periodontal tissue engineering. BioResearch Open Access. 2014;3:117-26.

[122] Preissner KT. Structure and biological role of vitronectin. Annual Review of Cell Biology. 1991;7:275-310.

[123] Preissner KT, Reuning U. In Seminars in thrombosis and hemostasis (OThieme Medical Publishers, 2011, pp. 408-24.

[124] Kundu AK, Putnam AJ. Vitronectin and collagen I differentially regulate osteogenesis in mesenchymal stem cells. Biochemical and Biophysical Research Communications. 2006;347:347-57.

[125] Lawley E, Baranov P, Young M. Hybrid vitronectinmimicking polycaprolactone scaffolds for human retinal progenitor cell differentiation and transplantation. Journal of Biomaterials Applications. 2015;29:894-902.

[126] Juhásová J, Juhas S, Klima J, Strnadel J, Holubova M, Motlik J. Osteogenic differentiation of miniature pig mesenchymal stem cells in 2D and 3D environment. Physiological Research. 2011;60:559.

[127] Diekjürgen D, Grainger DW. Polysaccharide matrices used in 3D in vitro cell culture systems. Biomaterials. 2017;141:96-115.

[128] Zarrintaj P, Manouchehri S, Ahmadi Z, Saeb MR, Urbanska AM, Kaplan DL, Mozafari M. Agarose-based biomaterials for tissue engineering. Carbohydrate Polymers. 2018; 187:66-84.

[129] Forget A, Christensen J, Lüdeke S, Kohler E, Tobias S, Matloubi M, Thomann R, Shastri VP. Polysaccha- 
ride hydrogels with tunable stiffness and provasculogenic properties via $\alpha$-helix to $\beta$-sheet switch in secondary structure. Proceedings of the National Academy of Sciences. 2013;110:12887-92.

[130] Mauck RL, Yuan X, Tuan RS. Chondrogenic differentiation and functional maturation of bovine mesenchymal stem cells in long-term agarose culture. Osteoarthritis Cartilage. 2006;14:179-89.

[131] Finger AR, Sargent CY, Dulaney KO, Bernacki SH, Loboa EG. Differential effects on messenger ribonucleic acid expression by bone marrow-derived human mesenchymal stem cells seeded in agarose constructs due to ramped and steady applications of cyclic hydrostatic pressure. Tissue Eng. 2007;13:1151-8.

[132] Awad HA, Wickham MQ, Leddy HA, Gimble JM, Guilak F. Chondrogenic differentiation of adipose-derived adult stem cells in agarose, alginate, and gelatin scaffolds. Biomaterials. 2004;25:3211-22.

[133] Huang CY, Reuben PM, D'Ippolito G, Schiller PC, Cheung HS. Chondrogenesis of human bone marrow-derived mesenchymal stem cells in agarose culture. Anat Rec A Discov Mol Cell Evol Biol. 2004;278:428-36.

[134] Chen SS, Fitzgerald W, Zimmerberg J, Kleinman HK, Margolis L. Cell-cell and cell-extracellular matrix interactions regulate embryonic stem cell differentiation. Stem Cells. 2007;25:553-61.

[135] Silva KR, Rezende RA, Pereira FD, Gruber P, Stuart MP, Ovsianikov A, Brakke K, Kasyanov V, da Silva JV, Granjeiro JM. Delivery of human adipose stem cells spheroids into lockyballs. PloS one. 2016;11:e0166073.

[136] Forget A, Blaeser A, Miessmer F, Köpf M, Campos DFD, Voelcker NH, Blencowe A, Fischer H, Shastri VP. Mechanically Tunable Bioink for 3D Bioprinting of Human Cells. Advanced Healthcare Materials. 2017;6.

[137] Forget A, Arya N, Randriantsilefisoa R, Miessmer F, Buck M, Ahmadi V, Jonas D, Blencowe A, Shastri VP. Nonwoven carboxylated agarose-based fiber meshes with antimicrobial properties. Biomacromolecules. 2016;17: 4021-6.

[138] Axpe E, Oyen ML. Applications of alginate-based bioinks in 3D bioprinting. International Journal of Molecular Sciences. 2016;17:1976.

[139] Li T, Li Z, Nan F, Dong J, Deng Y, Yu Q, Zhang T. Construction of a novel inducing system with multi-layered alginate microcapsules to regulate differentiation of neural precursor cells from bone mesenchymal stem cells. Medical Hypotheses. 2015;85:910-3.

[140] Razavi S, Khosravizadeh Z, Bahramian H, Kazemi M. Time-Dependent Effect of Encapsulating Alginate Hydrogel on Neurogenic Potential. Cell Journal (Yakhteh). 2015; $17: 304$.

[141] Vorwald CE, Ho SS, Whitehead J, Leach JK. HighThroughput Formation of Mesenchymal Stem Cell Spheroids and Entrapment in Alginate Hydrogels In Biomaterials for Tissue Engineering Springer, 2018, pp. 139-49.

[142] Gimi B, Nemani KV. Advances in alginate gel microencapsulation of therapeutic cells. Critical Reviews ${ }^{\mathrm{TM}}$ in Biomedical Engineering. 2013;41.

[143] Hannouche D, Terai H, Fuchs JR, Terada S, Zand S, Nasseri BA, Petite H, Sedel L, Vacanti JP. Engineering of implantable cartilaginous structures from bone marrow-derived mesenchymal stem cells. Tissue Eng. 2007;13:87-99.
[144] Jin X, Sun Y, Zhang K, Wang J, Shi T, Ju X, Lou S. Ectopic neocartilage formation from predifferentiated human adipose derived stem cells induced by adenoviral-mediated transfer of hTGF beta2. Biomaterials. 2007;28:29943003.

[145] Wayne JS, McDowell CL, Shields KJ, Tuan RS. In vivo response of polylactic acid-alginate scaffolds and bone marrow-derived cells for cartilage tissue engineering. Tissue Eng. 2005;11:953-963.

[146] Prang P, Muller R, Eljaouhari A, Heckmann K, Kunz W, Weber T, Faber C, Vroemen M, Bogdahn U, Weidner N. The promotion of oriented axonal regrowth in the injured spinal cord by alginate-based anisotropic capillary hydrogels. Biomaterials. 2006;27:3560-9.

[147] Hunt NC, Hallam D, Karimi A, Mellough CB, Chen J, Steel DH, Lako M. 3D culture of human pluripotent stem cells in RGD-alginate hydrogel improves retinal tissue development. Acta Biomaterialia. 2017;49:329-43.

[148] Ashton RS, Banerjee A, Punyani S, Schaffer DV, Kane RS. Scaffolds based on degradable alginate hydrogels and poly(lactide-co-glycolide) microspheres for stem cell culture. Biomaterials. 2007;28:5518-25.

[149] Maguire T, Novik E, Schloss R, Yarmush M. AlginatePLL microencapsulation: Effect on the differentiation of embryonic stem cells into hepatocytes. Biotechnol Bioeng. 2006;93:581-91.

[150] Gerecht-Nir S, Cohen S, Ziskind A, Itskovitz-Eldor J. Three-dimensional porous alginate scaffolds provide a conducive environment for generation of wellvascularized embryoid bodies from human embryonic stem cells. Biotechnol Bioeng. 2004;88:313-20.

[151] Lee KY, Jeong L, Kang YO, Lee SJ, Park WH. Electrospinning of polysaccharides for regenerative medicine. Advanced Drug Delivery Reviews. 2009;61:1020-32.

[152] Athirasala A, Tahayeri A, Thrivikraman G, França CM, Monteiro N, Tran V, Ferracane J, Bertassoni LE. A dentin-derived hydrogel bioink for 3D bioprinting of cell laden scaffolds for regenerative dentistry. Biofabrication. 2018;10:024101.

[153] Kang K, Kim Y, Jeon H, Lee SB, Kim JS, Park SA, Kim WD, Yang HM, Kim SJ, Jeong J. Three-Dimensional Bioprinting of Hepatic Structures with Directly Converted Hepatocyte-Like Cells. Tissue Engineering Part A. 2018;24:576-83.

[154] Nguyen D, Hägg DA, Forsman A, Ekholm J, Nimkingratana P, Brantsing C, Kalogeropoulos T, Zaunz S, Concaro S, Brittberg M. Cartilage tissue engineering by the 3D bioprinting of iPS cells in a nanocellulose/alginate bioink. Scientific Reports. 2017;7:658.

[155] Gu Q, Tomaskovic-Crook E, Lozano R, Chen Y, Kapsa RM, Zhou Q, Wallace GG, Crook JM. Functional 3D neural mini-tissues from printed gel-based bioink and human neural stem cells. Advanced Healthcare Materials. 2016;5:1429-38.

[156] Knopf-Marques H, Pravda M, Wolfova L, Velebny V, Schaaf P, Vrana NE, Lavalle P. Hyaluronic acid and its derivatives in coating and delivery systems: Applications in tissue engineering, regenerative medicine and immunomodulation. Advanced Healthcare Materials. 2016;5:2841-55.

[157] Haylock DN, Nilsson SK. The role of hyaluronic acid in hemopoietic stem cell biology. 2006.

[158] Gerecht S, Burdick JA, Ferreira LS, Townsend SA, Langer R, Vunjak-Novakovic G. Hyaluronic acid hydro- 
gel for controlled self-renewal and differentiation of human embryonic stem cells. Proc Natl Acad Sci U S A. 2007;104:11298-303.

[159] Dai Prè E, Conti G, Sbarbati A. Hyaluronic acid (Ha) scaffolds and multipotent stromal cells (Mscs) in regenerative medicine. Stem Cell Reviews and Reports. 2016;12: 664-81.

[160] Flynn L, Prestwich GD, Semple JL, Woodhouse KA. Adipose tissue engineering with naturally derived scaffolds and adipose-derived stem cells. Biomaterials. 2007;28: 3834-42.

[161] Flynn LE, Prestwich GD, Semple JL, Woodhouse KA. Proliferation and differentiation of adipose-derived stem cells on naturally derived scaffolds. Biomaterials. 2008.

[162] Myers SR, Partha VN, Soranzo C, Price RD, Navsaria HA. Hyalomatrix: A temporary epidermal barrier, hyaluronan delivery, and neodermis induction system for keratinocyte stem cell therapy. Tissue Eng. 2007;13:273341.

[163] Chen PY, Huang LL, Hsieh HJ. Hyaluronan preserves the proliferation and differentiation potentials of long-term cultured murine adipose-derived stromal cells. Biochem Biophys Res Commun. 2007;360:1-6.

[164] da Silva LP, Santos TC, Rodrigues DB, Pirraco RP, Cerqueira MT, Reis RL, Correlo VM, Marques AP. Stem Cell-Containing Hyaluronic Acid-Based Spongy Hydrogels for Integrated Diabetic Wound Healing. Journal of Investigative Dermatology. 2017;137:1541-51.

[165] Moshayedi P, Carmichael ST. Hyaluronan, neural stem cells and tissue reconstruction after acute ischemic stroke. Biomatter. 2013;3:e23863.

[166] Wu S, Xu R, Duan B, Jiang P. Three-dimensional hyaluronic acid hydrogel-based models for in vitro human iPSC-derived NPC culture and differentiation. Journal of Materials Chemistry B. 2017;5:3870-8.

[167] Amirian J, Van TTT, Bae S-H, Jung H-I, Choi H-J, Cho $\mathrm{H}-\mathrm{D}$, Lee B-T. Examination of In vitro and In vivo biocompatibility of alginate-hyaluronic acid microbeads As a promising method in cell delivery for kidney regeneration. International Journal of Biological Macromolecules. 2017; 105:143-53.

[168] Shendi D, Albrecht DR, Jain A. Anti-Fas conjugated hyaluronic acid microsphere gels for neural stem cell delivery. Journal of Biomedical Materials Research Part A. 2017;105:608-18.

[169] Zhao W, Liu W, Li J, Lin X, Wang Y. Preparation of animal polysaccharides nanofibers by electrospinning and their potential biomedical applications. Journal of Biomedical Materials Research Part A. 2015;103:807-18.

[170] Sakai S, Ohi H, Hotta T, Kamei H, Taya M. Differentiation potential of human adipose stem cells bioprinted with hyaluronic acid/gelatin-based bioink through microextrusion and visible light-initiated crosslinking. Biopolymers. 2018;109:e23080.

[171] Poldervaart MT, Goversen B, De Ruijter M, Abbadessa A, Melchels FP, Öner FC, Dhert WJ, Vermonden T, Alblas J. 3D bioprinting of methacrylated hyaluronic acid (MeHA) hydrogel with intrinsic osteogenicity. PloS one. 2017;12:e0177628.

[172] Law N, Doney B, Glover H, Qin Y, Aman ZM, Sercombe TB, Liew LJ, Dilley RJ, Doyle BJ. Characterisation of hyaluronic acid methylcellulose hydrogels for 3D bioprinting. Journal of the Mechanical Behavior of Biomedical Materials. 2018;77:389-99.
[173] Wan AC, Tai BC. CHITIN-A promising biomaterial for tissue engineering and stem cell technologies. Biotechnology Advances. 2013;31:1776-85.

[174] Chang S-H, Lin H-TV, Wu G-J, Tsai GJ. pH Effects on solubility, zeta potential, and correlation between antibacterial activity and molecular weight of chitosan. Carbohydrate Polymers. 2015;134:74-81.

[175] Muzzarelli RA, El Mehtedi M, Bottegoni C, Gigante A. Physical properties imparted by genipin to chitosan for tissue regeneration with human stem cells: A review. International Journal of Biological Macromolecules. 2016;93:1366-81.

[176] Gravel M, Gross T, Vago R, Tabrizian M. Responses of mesenchymal stem cell to chitosan-coralline composites microstructured using coralline as gas forming agent. Biomaterials. 2006;27:1899-906.

[177] LogithKumar R, KeshavNarayan A, Dhivya S, Chawla A, Saravanan S, Selvamurugan N. A review of chitosan and its derivatives in bone tissue engineering. Carbohydrate Polymers. 2016;151:172-88.

[178] Muzzarelli RA, El Mehtedi M, Bottegoni C, Aquili A, Gigante A. Genipin-crosslinked chitosan gels and scaffolds for tissue engineering and regeneration of cartilage and bone. Marine Drugs. 2015;13:7314-38.

[179] Li H, Ham TR, Neill N, Farrag M, Mohrman AE, Koenig AM, Leipzig ND. A hydrogel bridge incorporating immobilized growth factors and neural stem/progenitor cells to treat spinal cord injury. Advanced Healthcare Materials. 2016;5:802-12.

[180] Zhang J, Lu X, Feng G, Gu Z, Sun Y, Bao G, Xu G, Lu Y, Chen J, Xu L. Chitosan scaffolds induce human dental pulp stem cells to neural differentiation: Potential roles for spinal cord injury therapy. Cell and Tissue Research. 2016;366:129-42.

[181] Tao SC, Guo SC, Li M, Ke QF, Guo YP, Zhang CQ. Chitosan Wound Dressings Incorporating Exosomes Derived from MicroRNA-126-Overexpressing Synovium Mesenchymal Stem Cells Provide Sustained Release of Exosomes and Heal Full-Thickness Skin Defects in a Diabetic Rat Model. Stem Cells Translational Medicine. 2017;6:736-47.

[182] Franzesi GT, Ni B, Ling Y, Khademhosseini A. A controlled-release strategy for the generation of crosslinked hydrogel microstructures. J Am Chem Soc. 2006; 128:15064-5.

[183] Cho CH, Eliason JF, Matthew HW. Application of porous glycosaminoglycan-based scaffolds for expansion of human cord blood stem cells in perfusion culture. $\mathrm{J}$ Biomed Mater Res A. 2007.

[184] PP BM, Pedro AJ, Peterbauer A, Gabriel C, Redl H, Reis RL. Chitosan particles agglomerated scaffolds for cartilage and osteochondral tissue engineering approaches with adipose tissue derived stem cells. J Mater Sci Mater Med. 2005;16:1077-85.

[185] Azuma K, Ifuku S, Osaki T, Okamoto Y, Minami S. Preparation and biomedical applications of chitin and chitosan nanofibers. Journal of Biomedical Nanotechnology. 2014;10:2891-920.

[186] Razavi S, Zarkesh-Esfahani H, Morshed M, Vaezifar S, Karbasi S, Golozar MA. Nanobiocomposite of poly (lactide-co-glycolide)/chitosan electrospun scaffold can promote proliferation and transdifferentiation of Schwann-like cells from human adipose-derived stem cells. Journal of Biomedical Materials Research Part A. 2015;103:2628-34. 
[187] Roehm KD, Madihally SV. Bioprinted chitosan-gelatin thermosensitive hydrogels using an inexpensive 3D printer. Biofabrication. 2017;10:015002.

[188] Mohite BV, Patil SV. A novel biomaterial: Bacterial cellulose and its new era applications. Biotechnology and Applied Biochemistry. 2014;61:101-10.

[189] Nasatto PL, Pignon F, Silveira JL, Duarte MER, Noseda MD, Rinaudo M. Methylcellulose, a cellulose derivative with original physical properties and extended applications. Polymers. 2015;7:777-803.

[190] Pakulska MM, Ballios BG, Shoichet MS. Injectable hydrogels for central nervous system therapy. Biomedical Materials. 2012;7:024101.

[191] Shen H, Ma Y, Luo Y, Liu X, Zhang Z, Dai J. Directed osteogenic differentiation of mesenchymal stem cell in three-dimensional biodegradable methylcellulosebased scaffolds. Colloids and Surfaces B: Biointerfaces. 2015;135:332-8

[192] Ballios BG, Cooke MJ, Donaldson L, Coles BL, Morshead CM, van der Kooy D, Shoichet MS. A hyaluronan-based injectable hydrogel improves the survival and integration of stem cell progeny following transplantation. Stem Cell Reports. 2015;4:1031-45.

[193] Taylor DA, Sampaio LC, Ferdous Z, Gobin AS, Taite LJ. Decellularized Matrices in Regenerative Medicine. Acta Biomaterialia. 2018;74:74-89.

[194] Sun Y, Yan L, Chen S, Pei M. Functionality of decellularized matrix in cartilage regeneration: A comparison of tissue versus cell sources. Acta Biomaterialia. 2018.

[195] Anasiz Y, Ozgul RK, Uckan-Cetinkaya D. A new chapter for mesenchymal stem cells: Decellularized extracellular matrices. Stem Cell Reviews and Reports. 2017;13: 587-97.

[196] Shakouri-Motlagh A, O'Connor AJ, Brennecke SP, Kalionis B, Heath DE. Native and solubilized decellularized extracellular matrix: A critical assessment of their potential for improving the expansion of mesenchymal stem cells. Acta Biomaterialia. 2017;55:1-12.

[197] Khan AA, Vishwakarma SK, Bardia A, Venkateshwarulu J. Repopulation of decellularized whole organ scaffold using stem cells: An emerging technology for the development of neo-organ. Journal of Artificial Organs. 2014; 17:291-300.

[198] Choudhury D, Tun HW, Wang T, Naing MW. OrganDerived Decellularized Extracellular Matrix: A Game Changer for Bioink Manufacturing? Trends in Biotechnology. 2018;36(8):787-805.

[199] Keane TJ, Londono R, Turner NJ, Badylak SF. Consequences of ineffective decellularization of biologic scaffolds on the host response. Biomaterials. 2012;33: 1771-81.

[200] Engler AJ, Sen S, Sweeney HL, Discher DE. Matrix elasticity directs stem cell lineage specification. Cell. 2006;126:677-89.

[201] Xu Y, Kim CS, Saylor DM, Koo D. Polymer degradation and drug delivery in PLGA-based drug-polymer applications: A review of experiments and theories. Journal of Biomedical Materials Research Part B: Applied Biomaterials. 2017;105:1692-716.

[202] Song X, Zhao X, Zhou Y, Li S, Ma Q. Pharmacokinetics and disposition of various drug loaded biodegradable poly (lactide-co-glycolide)(PLGA) nanoparticles. Current Drug Metabolism. 2010;11:859-69.

[203] Lee PW, Pokorski JK. Poly (lactic-co-glycolic acid) devices: Production and applications for sustained protein delivery. Wiley Interdisciplinary Reviews: Nanomedicine and Nanobiotechnology. 2018; 1516.

[204] Kim H, Kim HW, Suh H. Sustained release of ascorbate2-phosphate and dexamethasone from porous PLGA scaffolds for bone tissue engineering using mesenchymal stem cells. Biomaterials. 2003;24:4671-9.

[205] Tomita M, Lavik E, Klassen H, Zahir T, Langer R, Young MJ. Biodegradable polymer composite grafts promote the survival and differentiation of retinal progenitor cells. Stem Cells. 2005;23:1579-88.

[206] Turhani D, Watzinger E, Weissenbock M, Yerit K, Cvik1 B, Thurnher D, Ewers R. Three-dimensional composites manufactured with human mesenchymal cambial layer precursor cells as an alternative for sinus floor augmentation: An in vitro study. Clin Oral Implants Res. 2005;16: 417-24.

[207] Bhang SH, Lim JS, Choi CY, Kwon YK, Kim BS. The behavior of neural stem cells on biodegradable synthetic polymers. J Biomater Sci Polym Ed. 2007;18: 223-39.

[208] Yoon E, Dhar S, Chun DE, Gharibjanian NA, Evans GR. In vivo osteogenic potential of human adipose-derived stem cells/poly lactide-co-glycolic acid constructs for bone regeneration in a rat critical-sized calvarial defect model. Tissue Eng. 2007;13:619-27.

[209] Worthington KS, Wiley LA, Guymon CA, Salem AK, Tucker BA. Differentiation of induced pluripotent stem cells to neural retinal precursor cells on porous polylactic-co-glycolic acid scaffolds. Journal of Ocular Pharmacology and Therapeutics. 2016;32:310-16.

[210] Lee H, Nguyen T, Kim M, Jeong JH, Park JB. The effects of biodegradable poly (lactic-co-glycolic acid)-based microspheres loaded with quercetin on stemness, viability and osteogenic differentiation potential of stem cell spheroids. Journal of Periodontal Research. 2018;53(5):801-15.

[211] Kaka G, Arum J, Sadraie SH, Emamgholi A, Mohammadi A. Bone Marrow Stromal Cells Associated with Poly L-Lactic-Co-Glycolic Acid (PLGA) Nanofiber Scaffold Improve Transected Sciatic Nerve Regeneration. Iranian Journal of Biotechnology. 2017;15:149-56.

[212] Knop K, Hoogenboom R, Fischer D, Schubert US. Poly (ethylene glycol) in drug delivery: Pros and cons as well as potential alternatives. Angewandte Chemie International Edition. 2010;49:6288-308.

[213] Acosta-Vélez GF, Zhu TZ, Linsley CS, Wu BM. Photocurable poly (ethylene glycol) as a bioink for the inkjet 3D pharming of hydrophobic drugs. International Journal of Pharmaceutics. 2018;546:145-53.

[214] Zhu J. Bioactive modification of poly (ethylene glycol) hydrogels for tissue engineering. Biomaterials. 2010;31:4639-56.

[215] Benoit DS, Anseth KS. Heparin functionalized PEG gels that modulate protein adsorption for hMSC adhesion and differentiation. Acta Biomater. 2005;1:461-70.

[216] Levenberg S, Burdick JA, Kraehenbuehl T, Langer R. Neurotrophin-induced differentiation of human embryonic stem cells on three-dimensional polymeric scaffolds. Tissue Eng. 2005;11:506-12.

[217] Mahoney MJ, Anseth KS. Three-dimensional growth and function of neural tissue in degradable polyethylene glycol hydrogels. Biomaterials. 2006;27:2265-74.

[218] Mahoney MJ, Anseth KS. Contrasting effects of collagen and bFGF-2 on neural cell function in degradable synthetic PEG hydrogels. J Biomed Mater Res A. 2007;81: 269-78. 
[219] Royce Hynes S, McGregor LM, Ford Rauch M, Lavik EB. Photopolymerized poly(ethylene glycol)/poly(L-lysine) hydrogels for the delivery of neural progenitor cells. J Biomater Sci Polym Ed. 2007;18:1017-30.

[220] Underhill GH, Chen AA, Albrecht DR, Bhatia SN. Assessment of hepatocellular function within PEG hydrogels. Biomaterials. 2007;28:256-70.

[221] Stosich MS, Bastian B, Marion NW, Clark PA, Reilly G, Mao JJ. Vascularized adipose tissue grafts from human mesenchymal stem cells with bioactive cues and microchannel conduits. Tissue Eng. 2007;13:2881-90.

[222] Benoit DS, Durney AR, Anseth KS. The effect of heparinfunctionalized PEG hydrogels on three-dimensional human mesenchymal stem cell osteogenic differentiation. Biomaterials. 2007;28:66-77.

[223] Salinas CN, Cole BB, Kasko AM, Anseth KS. Chondrogenic differentiation potential of human mesenchymal stem cells photoencapsulated within poly(ethylene glycol)-arginine-glycine-aspartic acid-serine thiolmethacrylate mixed-mode networks. Tissue Eng. 2007;13: 1025-34.

[224] Liu C, Huang Y, Pang M, Yang Y, Li S, Liu L, Shu T, Zhou W, Wang X, Rong L. Tissue-engineered regeneration of completely transected spinal cord using induced neural stem cells and gelatin-electrospun poly (lactideco-glycolide)/polyethylene glycol scaffolds. PloS one. 2015;10:e0117709.

[225] Mirzaei S, Karkhaneh A, Soleimani M, Ardeshirylajimi A, Zonouzi HS, Hanaee-Ahvaz H. Enhanced chondrogenic differentiation of stem cells using an optimized electrospun nanofibrous PLLA/PEG scaffolds loaded with glucosamine. Journal of Biomedical Materials Research Part A. 2017;105(9):2461-474.

[226] Miao T, Rao KS, Spees JL, Oldinski RA. Osteogenic differentiation of human mesenchymal stem cells through alginate-graft-poly (ethylene glycol) microspheremediated intracellular growth factor delivery. Journal of Controlled Release. 2014;192:57-66.

[227] Xu Q, Sigen A, Gao Y, Guo L, Creagh-Flynn J, Zhou D, Greiser U, Dong Y, Wang F, Tai H. A hybrid injectable hydrogel from hyperbranched PEG macromer as a stem cell delivery and retention platform for diabetic wound healing. Acta biomaterialia. 2018;75:63-74

[228] Gao G, Hubbell K, Schilling AF, Dai G, Cui X. Bioprinting Cartilage Tissue from Mesenchymal Stem Cells and PEG Hydrogel. 3D Cell Culture: Methods and Protocols. 2017;391-8

[229] Costantini M, Testa S, Mozetic P, Barbetta A, Fuoco C, Fornetti E, Tamiro F, Bernardini S, Jaroszewicz J, Święszkowski W. Microfluidic-enhanced 3D bioprinting of aligned myoblast-laden hydrogels leads to functionally organized myofibers in vitro and in vivo. Biomaterials. 2017;131:98-110.

[230] Siddiqui N, Asawa S, Birru B, Baadhe R, Rao S. PCL-Based Composite Scaffold Matrices for Tissue Engineering Applications. Molecular Biotechnology. 2018;1-27.

[231] Morrison RJ, Nasser HB, Kashlan KN, Zopf DA, Milner DJ, Flanangan CL, Wheeler MB, Green GE, Hollister SJ. Co-culture of adipose-derived stem cells and chondrocytes on three-dimensionally printed bioscaffolds for craniofacial cartilage engineering. The Laryngoscope. 2018;28(7):E251-E25.

[232] Ko J, Mohtaram NK, Ahmed F, Montgomery A, Carlson M, Lee PC, Willerth SM, Jun MB. Fabrication of poly
( $\epsilon$-caprolactone) microfiber scaffolds with varying topography and mechanical properties for stem cell-based tissue engineering applications. Journal of Biomaterials Science, Polymer Edition. 2014;25:1-17.

[233] Mohtaram NK, Ko J, King C, Sun L, Muller N, Jun MBG, Willerth SM. Electrospun biomaterial scaffolds with varied topographies for neuronal differentiation of human-induced pluripotent stem cells. Journal of Biomedical Materials Research Part A. 2015;103:2591-601.

[234] Wanjare M, Hou L, Nakayama KH, Kim JJ, Mezak NP, Abilez OJ, Tzatzalos E, Wu JC, Huang NF. Anisotropic microfibrous scaffolds enhance the organization and function of cardiomyocytes derived from induced pluripotent stem cells. Biomaterials Science. 2017;5:1567-78.

[235] Jauregui C, Yoganarasimha S, Madurantakam P. Mesenchymal Stem Cells Derived from Healthy and Diseased Human Gingiva Support Osteogenesis on Electrospun Polycaprolactone Scaffolds. Bioengineering. 2018;5:8.

[236] Brännmark C, Paul A, Ribeiro D, Magnusson B, Brolén G, Enejder A, Forslöw A. Increased adipogenesis of human adipose-derived stem cells on polycaprolactone fiber matrices. PLoS One. 2014;9:e113620.

[237] Wunner FM, Bas O, Saidy NT, Dalton PD, Pardo E, Hutmacher DW. Melt Electrospinning Writing of Three-dimensional Poly ( $\varepsilon$-caprolactone) Scaffolds with Controllable Morphologies for Tissue Engineering Applications. Journal of visualized experiments: JoVE. 2017; 130:e56289.

[238] Hernandez I, Kumar A, Joddar B. A Bioactive Hydrogel and 3D Printed Polycaprolactone System for Bone Tissue Engineering. Gels. 2017;3:26.

[239] Agbay A, De La Vega L, Nixon G, Willerth S. Guggulsterone-releasing microspheres direct the differentiation of human induced pluripotent stem cells into neural phenotypes. Biomedical Materials. 2018;13:034104.

[240] Gomez JC, Edgar JM, Agbay AM, Bibault E, Montgomery A, Mohtaram NK, Willerth SM. Incorporation of retinoic acid releasing microspheres into pluripotent stem cell aggregates for inducing neuronal differentiation. Cellular and Molecular Bioengineering. 2015;8:307-19.

[241] Mkhabela VJ, Ray SS. Poly ( $\varepsilon$-caprolactone) nanocomposite scaffolds for tissue engineering: A brief overview. Journal of Nanoscience and Nanotechnology. 2014;14:535-45.

[242] Balint R, Cassidy NJ, Cartmell SH. Conductive polymers: Towards a smart biomaterial for tissue engineering. Acta Biomaterialia. 2014;10:2341-53.

[243] Serra Moreno J, Sabbieti MG, Agas D, Marchetti L, Panero S. Polysaccharides immobilized in polypyrrole matrices are able to induce osteogenic differentiation in mouse mesenchymal stem cells. Journal of Tissue Engineering and Regenerative Medicine. 2014;8:989-99.

[244] Saigal R, Cimetta E, Tandon N, Zhou J, Langer R, Young M, Vunjak-Novakovic G, Redenti S. in Engineering in Medicine and Biology Society (EMBC), 2013 35th Annual International Conference of the IEEE IEEE, 2013, pp. 1627-31.

[245] Hu W-W, Hsu Y-T, Cheng Y-C, Li C, Ruaan R-C, Chien C-C, Chung C-A, Tsao C-W. Electrical stimulation to promote osteogenesis using conductive polypyrrole films. Materials Science and Engineering: C 37, 2014, 28-36.

[246] Spearman BS, Hodge AJ, Porter JL, Hardy JG, Davis $\mathrm{ZD}$, Xu T, Zhang X, Schmidt CE, Hamilton MC, Lipke EA. Conductive interpenetrating networks of polypyrrole and polycaprolactone encourage electrophys- 
iological development of cardiac cells. Acta Biomaterialia. 2015;28:109-20.

[247] Hardy JG, Villancio-Wolter MK, Sukhavasi RC, Mouser DJ, Aguilar D, Geissler SA, Kaplan DL, Schmidt CE. Electrical stimulation of human mesenchymal stem cells on conductive nanofibers enhances their differentiation toward osteogenic outcomes. Macromolecular Rapid Communications. 2015;36:1884-90.

[248] Yang S, Jang L, Kim S, Yang J, Yang K, Cho SW, Lee JY. Polypyrrole/alginate hybrid hydrogels: Electrically conductive and soft biomaterials for human mesenchymal stem cell culture and potential neural tissue engineering applications. Macromolecular Bioscience. 2016;16: 1653-61.

[249] Lin X, Shi Y, Cao Y, Liu W. Recent progress in stem cell differentiation directed by material and mechanical cues. Biomedical Materials. 2016;11:014109.

[250] Regehr KJ, Domenech M, Koepsel JT, Carver KC, EllisonZelski SJ, Murphy WL, Schuler LA, Alarid ET, Beebe DJ. Biological implications of polydimethylsiloxane-based microfluidic cell culture. Lab on a Chip. 2009;9:2132-9.

[251] Sivarapatna A, Ghaedi M, Xiao Y, Han E, Aryal B, Zhou J, Fernandez-Hernando C, Qyang Y, Hirschi KK, Niklason LE. Engineered Microvasculature in PDMS Networks Using Endothelial Cells Derived from Human Induced Pluripotent Stem Cells. Cell Transplantation. 2017;26:1365-79.

[252] Aguilar VM, Cosgrove BD. Microcontact-Printed Hydrogel Microwell Arrays for Clonal Muscle Stem Cell Cultures In Skeletal Muscle Development Springer, 2017, pp. 75-92.

[253] Smith Q, Chan XY, Carmo AM, Trempel M, Saunders $\mathrm{M}$, Gerecht S. Compliant substratum guides endothelial commitment from human pluripotent stem cells. Science Advances. 2017;3:e1602883.

[254] Abbasi F, Ghanian MH, Baharvand H, Vahidi B, Eslaminejad MB. Engineering mesenchymal stem cell spheroids by incorporation of mechanoregulator microparticles. Journal of the Mechanical Behavior of Biomedical Materials. 2018;84:74-87.

[255] Li Y. PCL-PDMS-PCL copolymer-based microspheres mediate cardiovascular differentiation from embryonic stem cells. 2016.

[256] Zhang S. Discovery and design of self-assembling peptides. Interface Focus. 2017;7:20170028.

[257] Silva GA, Czeisler C, Niece KL, Beniash E, Harrington DA, Kessler JA, Stupp SI. Selective differentiation of neural progenitor cells by high-epitope density nanofibers. Science. 2004;303:1352-5.

[258] Matsuzawa M, Weight FF, Potember RS, Liesi P. Directional neurite outgrowth and axonal differentiation of embryonic hippocampal neurons are promoted by a neurite outgrowth domain of the B2-chain of laminin. Int $\mathrm{J}$ Dev Neurosci. 1996;14:283-95.

[259] Hosseinkhani H, Hosseinkhani M, Tian F, Kobayashi H, Tabata Y. Osteogenic differentiation of mesenchymal stem cells in self-assembled peptide-amphiphile nanofibers. Biomaterials. 2006;27:4079-86.

[260] Siddiqui AM, Khazaei M, Fehlings MG. Translating mechanisms of neuroprotection, regeneration, and repair to treatment of spinal cord injury In Progress in brain research Elsevier, 2015, pp. 15-54.

[261] Zamuner A, Cavo M, Scaglione S, Messina GML, Russo T, Gloria A, Marletta G, Dettin M. Design of Decorated Self-Assembling Peptide Hydrogels as Archi- tecture for Mesenchymal Stem Cells. Materials (Basel). 2016;9.

[262] Garreta E, Genove E, Borros S, Semino CE. Osteogenic differentiation of mouse embryonic stem cells and mouse embryonic fibroblasts in a three-dimensional selfassembling peptide scaffold. Tissue Eng. 2006;12:221527.

[263] Garreta E, Gasset D, Semino C, Borros S. Fabrication of a three-dimensional nanostructured biomaterial for tissue engineering of bone. Biomol Eng. 2007;24:75-80.

[264] Gelain F, Bottai D, Vescovi A, Zhang S. Designer selfassembling Peptide nanofiber scaffolds for adult mouse neural stem cell 3-dimensional cultures. PLoS ONE. 2006;1:e119.

[265] Guo H-d, Cui G-h, Wang H-j, Tan Y-z. Transplantation of marrow-derived cardiac stem cells carried in designer selfassembling peptide nanofibers improves cardiac function after myocardial infarction. Biochemical and Biophysical Research Communications. 2010;399:42-8.

[266] Cunha C, Panseri S, Villa O, Silva D, Gelain F. 3D culture of adult mouse neural stem cells within functionalized self-assembling peptide scaffolds. International Journal of Nanomedicine. 2011;6:943.

[267] Liu X, Wang X, Wang X, Ren H, He J, Qiao L, Cui F-Z. Functionalized self-assembling peptide nanofiber hydrogels mimic stem cell niche to control human adipose stem cell behavior in vitro. Acta Biomaterialia. 2013;9:6798805.

[268] Wu G, Pan M, Wang X, Wen J, Cao S, Li Z, Li Y, Qian C, Liu Z, Wu W. Osteogenesis of peripheral blood mesenchymal stem cells in self assembling peptide nanofiber for healing critical size calvarial bony defect. Scientific Reports. 2015;5:16681.

[269] Dziadek M, Stodolak-Zych E, Cholewa-Kowalska K. Biodegradable ceramic-polymer composites for biomedical applications: A review. Materials Science and Engineering: C 71. 2017;1175-91.

[270] Jones JR. Reprint of: Review of bioactive glass: From Hench to hybrids. Acta Biomaterialia. 2015;23: S53-S82.

[271] Velard F, Schlaubitz S, Fricain J-C, Guillaume C, LaurentMaquin D, Möller-Siegert J, Vidal L, Jallot E, Sayen S, Raissle O. In vitro and in vivo evaluation of the inflammatory potential of various nanoporous hydroxyapatite biomaterials. Nanomedicine. 2015;10:785-802.

[272] Yang XB, Webb D, Blaker J, Boccaccini AR, Maquet V, Cooper C, Oreffo RO. Evaluation of human bone marrow stromal cell growth on biodegradable polymer/bioglass composites. Biochem Biophys Res Commun. 2006;342:1098-107.

[273] Yamada Y, Boo JS, Ozawa R, Nagasaka T, Okazaki Y, Hata $\mathrm{K}$, Ueda M. Bone regeneration following injection of mesenchymal stem cells and fibrin glue with a biodegradable scaffold. J Craniomaxillofac Surg. 2003;31:27-33.

[274] Toquet J, Rohanizadeh R, Guicheux J, Couillaud S, Passuti N, Daculsi G, Heymann D. Osteogenic potential in vitro of human bone marrow cells cultured on macroporous biphasic calcium phosphate ceramic. J Biomed Mater Res. 1999;44:98-108.

[275] Shimaoka H, Dohi Y, Ohgushi H, Ikeuchi M, Okamoto M, Kudo A, Kirita T, Yonemasu K. Recombinant growth/differentiation factor-5 (GDF-5) stimulates osteogenic differentiation of marrow mesenchymal stem cells in porous hydroxyapatite ceramic. J Biomed Mater Res A. 2004;68:168-76. 
[276] Ohgushi H, Dohi Y, Yoshikawa T, Tamai S, Tabata S, Okunaga K, Shibuya T. Osteogenic differentiation of cultured marrow stromal stem cells on the surface of bioactive glass ceramics. J Biomed Mater Res. 1996;32:341-8.

[277] Meseguer-Olmo L, Bernabeu-Esclapez A, Ros-Martinez E, Sanchez-Salcedo S, Padilla S, Martin AI, Vallet-Regi M, Clavel-Sainz M, Lopez-Prats F, Meseguer-Ortiz CL. In vitro behaviour of adult mesenchymal stem cells seeded on a bioactive glass ceramic in the $\mathrm{SiO}(2)-\mathrm{CaO}-\mathrm{P}(2) \mathrm{O}(5)$ system. Acta Biomater. 2007;4(4):1104-113.

[278] Marcacci M, Kon E, Moukhachev V, Lavroukov A, Kutepov S, Quarto R, Mastrogiacomo M, Cancedda R. Stem cells associated with macroporous bioceramics for long bone repair: 6- to 7-year outcome of a pilot clinical study. Tissue Eng. 2007;13:947-55.

[279] Lennon DP, Haynesworth SE, Young RG, Dennis JE, Caplan AI. A chemically defined medium supports in vitro proliferation and maintains the osteochondral potential of rat marrow-derived mesenchymal stem cells. Exp Cell Res. 1995;219:211-22.

[280] Kruyt MC, Wilson CE, de Bruijn JD, van Blitterswijk CA, Oner CF, Verbout AJ, Dhert WJ. The effect of cell-based bone tissue engineering in a goat transverse process model. Biomaterials. 2006;27:5099-106.

[281] Kotobuki N, Ioku K, Kawagoe D, Fujimori H, Goto S, Ohgushi H. Observation of osteogenic differentiation cascade of living mesenchymal stem cells on transparent hydroxyapatite ceramics. Biomaterials. 2005;26:779-85.

[282] Kitamura S, Ohgushi H, Hirose M, Funaoka H, Takakura $\mathrm{Y}$, Ito $\mathrm{H}$. Osteogenic differentiation of human bone marrow-derived mesenchymal cells cultured on alumina ceramics. Artif Organs. 2004;28:72-82.

[283] Hanada K, Dennis JE, Caplan AI. Stimulatory effects of basic fibroblast growth factor and bone morphogenetic protein-2 on osteogenic differentiation of rat bone marrowderived mesenchymal stem cells. J Bone Miner Res. 1997;12:1606-14.

[284] Gao J, Dennis JE, Solchaga LA, Awadallah AS, Goldberg VM, Caplan AI. Tissue-engineered fabrication of an osteochondral composite graft using rat bone marrow-derived mesenchymal stem cells. Tissue Eng. 2001;7:363-71.

[285] Dyson JA, Genever PG, Dalgarno KW, Wood DJ. Development of custom-built bone scaffolds using mesenchymal stem cells and apatite-wollastonite glass-ceramics. Tissue Eng. 2007;13:2891-901.
[286] Dennis JE, Caplan AI. Porous ceramic vehicles for rat-marrow-derived (Rattus norvegicus) osteogenic cell delivery: Effects of pre-treatment with fibronectin or laminin. J Oral Implantol. 1993;19:106-115; discussion 136-107.

[287] Bruder SP, Kurth AA, Shea M, Hayes WC, Jaiswal N, Kadiyala $S$. Bone regeneration by implantation of purified, culture-expanded human mesenchymal stem cells. J Orthop Res. 1998; 16:155-62.

[288] Arinzeh TL, Tran T, McAlary J, Daculsi G. A comparative study of biphasic calcium phosphate ceramics for human mesenchymal stem-cell-induced bone formation. Biomaterials. 2005;26:3631-8.

[289] Arinzeh TL, Peter SJ, Archambault MP, van den Bos C, Gordon S, Kraus K, Smith A, Kadiyala S. Allogeneic mesenchymal stem cells regenerate bone in a critical-sized canine segmental defect. J Bone Joint Surg Am 85-A. 2003;1927-35.

[290] Moriguchi Y, Lee D-S, Chijimatsu R, Thamina K, Masuda K, Itsuki D, Yoshikawa H, Hamaguchi S, Myoui A. Impact of non-thermal plasma surface modification on porous calcium hydroxyapatite ceramics for bone regeneration. PloS one. 2018;13:e0194303.

[291] Gao C, Peng S, Feng P, Shuai C. Bone biomaterials and interactions with stem cells. Bone Research. 2017;5:17059.

[292] Rezwan K, Chen QZ, Blaker JJ, Boccaccini AR. Biodegradable and bioactive porous polymer/inorganic composite scaffolds for bone tissue engineering. Biomaterials. 2006;27:3413-31.

[293] Guarino V, Causa F, Ambrosio L. Bioactive scaffolds for bone and ligament tissue. Expert Rev Med Devices. 2007;4:405-18.

[294] Lee SH, Shin H. Matrices and scaffolds for delivery of bioactive molecules in bone and cartilage tissue engineering. Adv Drug Deliv Rev. 2007;59:339-59.

[295] Turnbull G, Clarke J, Picard F, Riches P, Jia L, Han F, Li B, Shu W. 3D bioactive composite scaffolds for bone tissue engineering. Bioactive Materials. 2017;3(3):278-314. 